\title{
Building student-staff partnerships in higher education
}

Citation for published version (APA):

Martens, S. E. (2021). Building student-staff partnerships in higher education. [Doctoral Thesis, Maastricht University]. Maastricht University. https://doi.org/10.26481/dis.20211015sm

Document status and date:

Published: 01/01/2021

DOI:

10.26481/dis.20211015sm

Document Version:

Publisher's PDF, also known as Version of record

\section{Please check the document version of this publication:}

- A submitted manuscript is the version of the article upon submission and before peer-review. There can be important differences between the submitted version and the official published version of record.

People interested in the research are advised to contact the author for the final version of the publication, or visit the DOI to the publisher's website.

- The final author version and the galley proof are versions of the publication after peer review.

- The final published version features the final layout of the paper including the volume, issue and page numbers.

Link to publication

\footnotetext{
General rights rights.

- You may freely distribute the URL identifying the publication in the public portal. please follow below link for the End User Agreement:

www.umlib.nl/taverne-license

Take down policy

If you believe that this document breaches copyright please contact us at:

repository@maastrichtuniversity.nl

providing details and we will investigate your claim.
}

Copyright and moral rights for the publications made accessible in the public portal are retained by the authors and/or other copyright owners and it is a condition of accessing publications that users recognise and abide by the legal requirements associated with these

- Users may download and print one copy of any publication from the public portal for the purpose of private study or research.

- You may not further distribute the material or use it for any profit-making activity or commercial gain

If the publication is distributed under the terms of Article $25 \mathrm{fa}$ of the Dutch Copyright Act, indicated by the "Taverne" license above, 


\section{Building student-staff partnerships in}

\section{higher education}





\section{Building student-staff partnerships in higher education}

Samantha Eeke Martens 
The research reported here was carried out at

\section{Maastricht University $(2$ Maastricht UMC+}

In the School of Health Professions Education

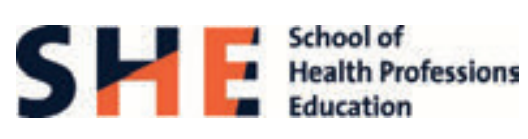

In the context of the research school

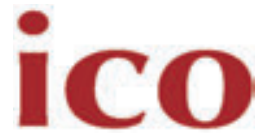

(Interuniversity Center for Educational Research)

ISBN:

978-94-6416-740-5

Illustrations:

Rosanne Martens

Lay-out:

Publiss

Print:

Ridderprint

(c) Copyright 2021: Samantha Eeke Martens, The Netherlands

All rights reserved. No part of this publication may be reproduced, stored in a retrieval system, or transmitted in any form or by any means, electronic, mechanical, by photocopying, recording, or otherwise, without the prior written permission of the author. 


\title{
Building student-staff partnerships in higher education
}

\author{
PROEFSCHRIFT \\ Ter verkrijging van de graad van doctor aan de Universiteit Maastricht, \\ op gezag van de Rector Magnificus, Prof. Dr. Rianne M. Letschert, \\ volgens het besluit van het College van Decanen, \\ in het openbaar te verdedigen
}

op vrijdag, 15 oktober 2021 om 12.00 uur

door

Samantha Eeke Martens 
Promotor

Copromotoren

Beoordelingscommissie
Prof. Dr. D.H.J.M. Dolmans

Dr. H.A.P. Wolfhagen

Dr. J.R.D. Whittingham

Prof. Dr. J.M. de Nooijer (voorzitter)

Prof. Dr. S.M.M. Loyens, Universiteit Utrecht

Prof. Dr. C.R.M.G. Fluit, Radboud UMC

Prof. Dr. J.P. Kooman

Dr. B.J.A. Janssen 


\section{Table of Contents}

Chapter 1 General introduction 1

$\begin{array}{lll}\text { Chapter } 2 & \text { A students' take on student-staff partnerships: } & 11\end{array}$

Experiences and preferences

Assessment and Evaluation in Higher Education (2019);

44(6), 910-919.

Chapter $3 \quad$ Student-staff partnerships for the broader student 31

population

Submitted

Chapter $4 \quad$ Behind the scenes - A path analysis of prerequisites for 51 student-staff partnerships

Submitted

Chapter $5 \quad$ Mind the gap: Teachers' conceptions of student-staff

69 partnership and its potential to enhance educational quality

Medical Teacher (2020); 42(5), 529-535.

Chapter 6 Student participation in the design of learning and teaching: Disentangling the terminology

Medical Teacher (2019); 41(10), 1203-1205.

$\begin{array}{lll}\text { Chapter } 7 & \text { General discussion } & 103\end{array}$

$\begin{array}{lll}\text { Addendum Summary } & 118\end{array}$

Samenvatting 123

Impact chapter 129

Dankwoord 133

$\begin{array}{ll}\text { About the author } & 137\end{array}$

SHE dissertation series $\quad 138$

$\begin{array}{ll}\text { ICO dissertation series } & 140\end{array}$ 


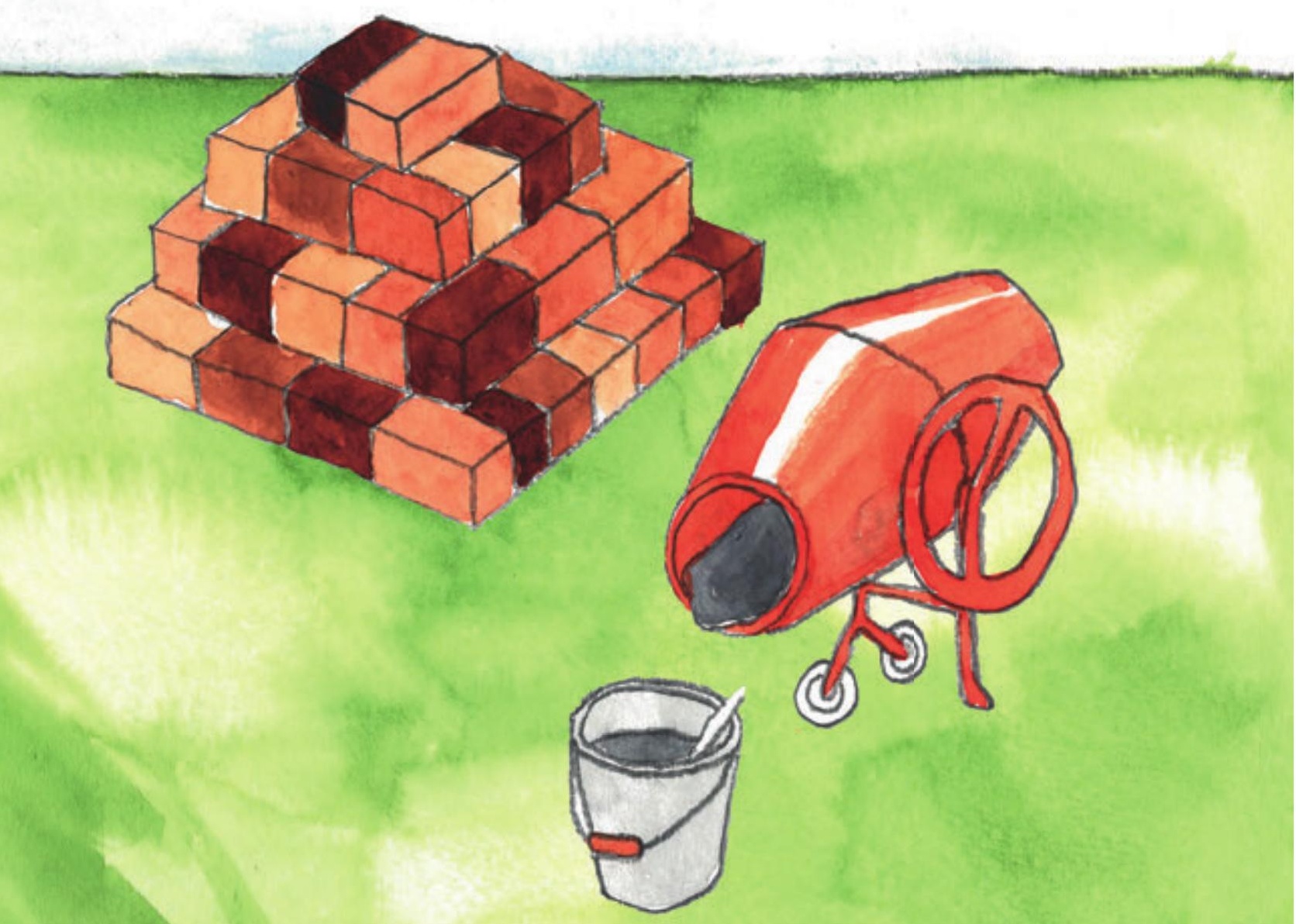


Chapter 1

General introduction 


\section{Introduction}

The idea of engaging students more actively in efforts to improve higher education has received greater attention in the last decade (e.g. Bovill, 2014; Gravett, Kinchin, \& Winstone, 2019; Mercer-Mapstone et al., 2017; Moore-Cherry, Healey, Nicholson, \& Andrews, 2016). Rather than being viewed as mere customers of education who consume what is being taught (e.g. Moore-Cherry et al., 2016), students are nowadays more often perceived as important stakeholders in the process of enhancing educational quality. One way to shape this in practice is by establishing so-called student-staff partnerships (SSPS) (Isaeva, Eisenschmidt, Vanari, \& Kumpas-Lenk, 2020). An SSP is "a collaborative, reciprocal process through which all participants have the opportunity to contribute equally, although not necessarily in the same ways, to curricular or pedagogical conceptualization, decision making, implementation, investigation or analysis" (Cook-Sather, Bovill, \& Felten, 2014, pp. 6-7). SSPs create the opportunity for students and staff members to work together on the design of education, make shared decisions to improve education, and collaborate to implement educational improvements.

Partnerships appear when students and staff members collaborate, for instance when designing, redesigning, or improving a particular course, by sharing their experiences and perspectives as a learner and teacher, respectively. In doing so, both partners deepen their understanding, which, in turn, may enhance educational improvements (Cook-Sather et al., 2014). Both stakeholders bring their different perspectives to an encounter which creates opportunities for discussions and new insights (Abbot \& Cook-Sather, 2020; Cook-Sather, 2015; Stevens, Wiltens, \& Koetsenruijter, 2010). Although these different perspectives and backgrounds can lead to disagreements, they can also be productive. That is, discussions present an opportunity to clarify each other's experiences and perspectives and resolve disagreements or come to a compromise (Abbot \& CookSather, 2020). Ultimately, combining students and staff members' experiences and perspectives can lead to enhanced teaching and learning practices (Isaeva et al., 2020; Könings, Seidel, \& van Merriënboer, 2014; Matthews, Dwyer, Hine, \& Turner, 2018).

This dissertation focuses on SSPs in learning and teaching. Several levels of student participation have been described in the literature, including SSPs (Bovill \& Bulley, 2011; Fielding, 2011; HEA NUS, 2011). We have translated these student participation levels to the following three stages: (1) No student involvement, 
(2) students provide feedback to inform and give advice to staff members, and

(3) students and staff members co-create by contributing equally to improving teaching and learning in SSPs. In the first stage, students do not participate at all or they just share their thoughts and suggestions, while staff do not act upon their suggestions (Bovill \& Bulley, 2011). In the second stage, students for instance provide feedback in end-of-course evaluation questionnaires or in program advisory committees that staff members can act upon. However, their input stays limited to the provision of feedback or advice as staff members are still in charge of enhancing educational quality (Bovill \& Bulley, 2011; HEA NUS, 2011). Finally, in the third stage, students and staff members contribute equally to decision-making and implementation processes in SSPs (Cook-Sather et al., 2014; Williamson, 2013). In so doing, it is important that both partners participate in the implementation process, as underscored by Williamson (2013): "[SSP] goes far beyond the mere consultation, involvement, or representation of students in decision-making. Where partnership exists, students not only identify areas for enhancement, but they help to identify ways to carry out that enhancement, as well as helping to facilitate implementation where possible" (p. 8). As the level of student participation increases across these stages, so do students' responsibilities for enhancing educational quality. An example of an SSP would be a staff member inviting students to be involved in the redesign and implementation of an existing course and in its eventual evaluation.

This begs the question: What do we already know about SSPs? Despite the fact that several examples of SSPs have been reported in the literature (Gibbs, 2010; Healey et al., 2014; Healey \& Healey, 2019; Williamson, 2013), little empirical evidence exists as yet on how to attain SSPs, especially in course and curriculum design (Healey \& Healey, 2019). There is a paucity of information on how students experience their current involvement in efforts to improve education and on what their preferences are. What we do know is that the few students who were more deeply involved in course improvements did not always feel appreciated, respected, and valued (Bicket, Misra, Wright, \& Shochet., 2010). This made us wonder: How do students actually experience these partnerships and do they want to participate in SSPs? Moreover, are all students willing to participate in SSPs or does such participation appeal only to students who are already actively involved, for instance in evaluation panels or course design/redesign teams? In other words, what are students' current experiences and preferences regarding SSPs? 
The next question that arises, then, is: What prerequisites are expected to facilitate SSP formation? According to Cook-Sather et al. (2014), the main prerequisites for a successful SSP are respect, reciprocity, and responsibility. By respect they mean "taking seriously and valuing what someone else or multiple others bring to an encounter" (Cook-Sather et al., 2014, p. 2). The second prerequisite, reciprocity, denotes "a way of interacting, ... a process of balanced give-and-take; there is equity in what is exchanged and how it is exchanged" (Cook-Sather et al., 2014, p. 3). Finally, responsibility implies that "it is up to the entire community to make learning spaces function" (Cook-Sather et al., 2014, p. 5). Other authors have flagged (shared) ownership (e.g., Wildridge et al., 2004), empowerment (Healey et al., 2014), and commitment (e.g., Dickerson, Jarvis, \& Stockwell, 2016) as important prerequisites for partnership. Pierce, Kostova, and Dirks (2003) defined ownership as "the [psychological] state in which individuals feel as though the target of ownership or a piece of that target is 'theirs"' (p. 86). Shared ownership, moreover, refers to a "mutual responsibility" (Bendermacher, Oude Egbrink, Wolfhagen, \& Dolmans, 2016, p. 14) and, as such, can be compared to Cook-Sather et al.'s (2014) definition of responsibility. With respect to empowerment, Menon (1999) defined this prerequisite as "a cognitive state characterized by a sense of perceived control, perceptions of competence, and internalization of the goals and objectives of the organization" (p. 161). The last prerequisite, commitment, refers to "the willingness to put extra effort into one's work and a tendency to be concerned with its quality" (Bendermacher et al., 2016, p. 14). In sum, respect, reciprocity, responsibility/ownership, empowerment, and commitment are variables perceived crucial for the success of SSPs. Yet, little is known to date about students and staff members' perceptions of what is needed to facilitate SSPs. In other words, what prerequisites are essential to enhance SSPs?

Traditionally, in higher education there is a clear distinction between staff and student perspectives. That is, staff members teach the content or particular subjects and students must acquire insight into the subjects being taught. In SSPs, however, students are positioned differently, which staff members may experience as troublesome: They might face barriers to implementing SSPs as this would take extra time or could spark disagreement, in turn making them feel reluctant to empower students (Bovill et al., 2016). Importantly, staff members' conceptions of SSPs have hitherto not been fully explored. Active student participation in the form of SSPS is an exception rather than the rule (Bovill, 2013). To be able 
to promote successful SSP formation, it is important to investigate different stakeholder perspectives. Hence, the aim of this PhD dissertation was to explore SSPs, by addressing the following research questions:

1. What are students' current experiences and preferences regarding SSPS, and the prerequisites to making a useful contribution to SSPs? (Chapters 2, 3, and 4)

2. What are staff members' conceptions of SSPs and of the prerequisites that render SSPs effective? (Chapter 5)

\section{Setting}

We conducted the studies in the present dissertation in several undergraduate programs of the Faculty of Health, Medicine, and Life Sciences at Maastricht University, the Netherlands. The programs we included were: Biomedical Sciences, Medicine, Health Sciences, and European Public Health.

Maastricht University uses a Problem-Based Learning (PBL) approach in which students, guided by a staff member, collaborate in small groups of approximately 11 students. During the first, preliminary meeting, students receive a description of a problem and identify what they already know about the subject and which questions remain unanswered. This meeting is followed by a self-study phase in which students search for answers to the questions they posed. In the next, post-discussion group meeting, students, again guided by a staff member, discuss the answers they found (Dolmans, 2019). Throughout these small-group sessions, students are encouraged to actively engage in the discussions.

Students within this setting are asked to fill in evaluation questionnaires at the end of each course. Some students participate in evaluation panels, educational committees, the management team, or in participate in course design teams. Students who participate in a course design team (usually two per team) meet to evaluate and discuss issues in need of improvement in a course.

\section{Outline of this dissertation}

Chapter 2 investigates the perspective of students who are already actively involved in efforts to enhance educational quality, for instance in evaluation panels or course design/redesign teams. This study aimed to measure students' experiences and their preferences regarding SSPs and their prerequisites. Chapter 3 extends 
this research by focusing on the perspective of a diverse group of students, the broader student population of a program. That is, the sample includes not only a select group of students who participate actively in, for instance, advisory bodies or course design teams, but also students who would otherwise not be actively involved in efforts to improve education. This study investigates students' experiences, their preferences, and the discrepancies between these two in terms of students' role as adviser and partner. Chapter 4 investigates how different prerequisites are statistically connected to SSP from students' perspective. This chapter explores the relationships between a supportive organisation and SSP and whether and how reciprocal respect, commitment and communication act as mediating variables. Chapter $\mathbf{5}$ addresses staff members', and more specifically, course coordinators' conceptions of student participation levels and of what is necessary to reach a beneficial SSP. Finally, Chapter 6 presents an overview of the similarities and differences between three terms frequently used related to the design of learning and teaching: Design-based research, participatory design, and co-creation, in terms of their aims and approaches to student participation. In Chapter $\mathbf{7}$ we will discuss the main findings of this dissertation. Table 1 gives an overview of the five studies that help us to answer the questions stated above. As this dissertation is based on several individual studies, some overlap is inevitable. 


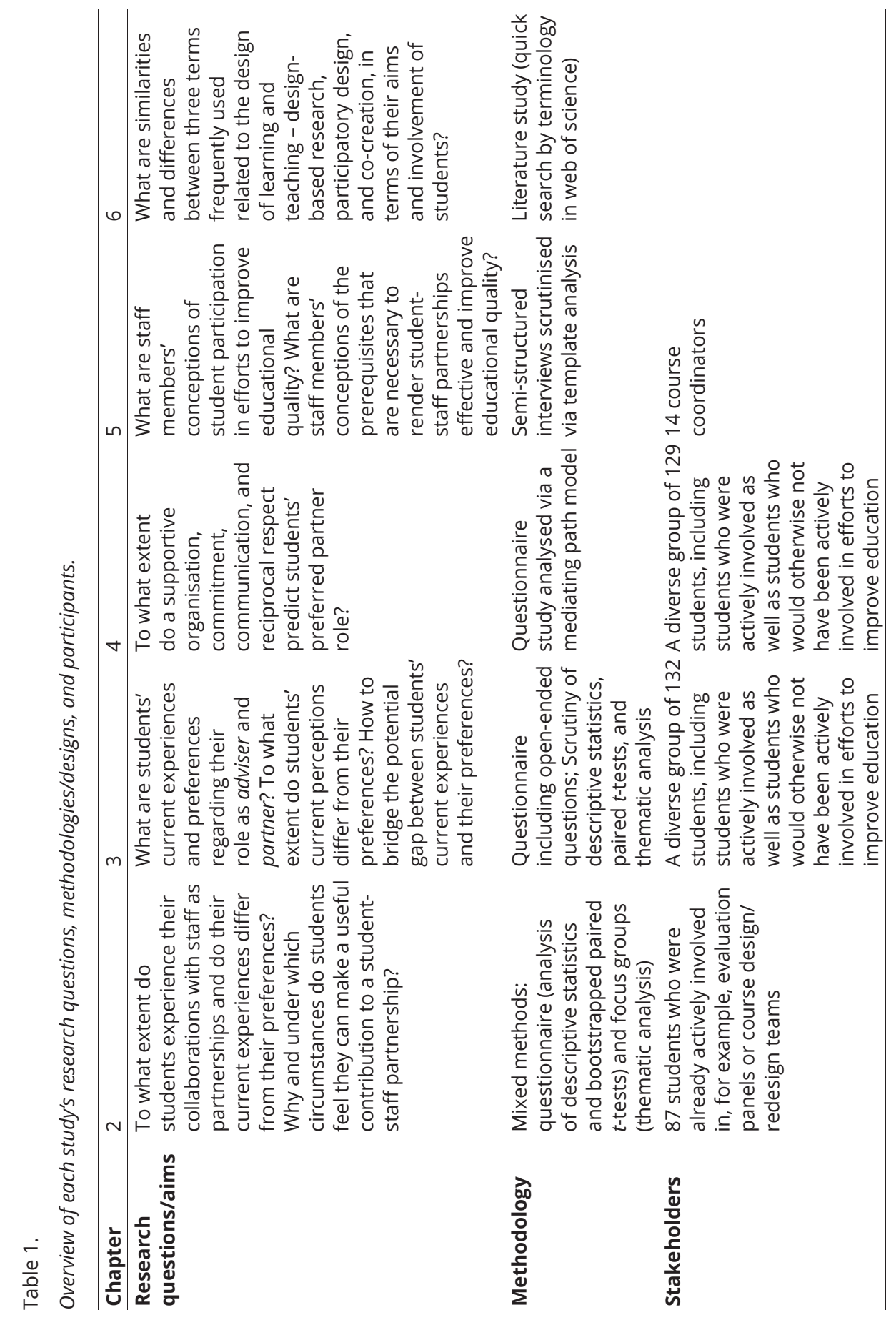




\section{References}

Abbot, S., \& Cook-Sather, A. (2020). The productive potential of pedagogical disagreements in classroom-focused student-staff partnerships. Higher Education Research and Development, 39(7), 1396-1409. https://doi.org/10.1080/07294360.2020.1735315

Bendermacher, G. W. G., Oude Egbrink, M. G. A., Wolfhagen, I. H. A. P., \& Dolmans, D. H. J. M. (2016). Unravelling quality culture in higher education: a realist review. Higher Education, 1-22. https://doi.org/10.1007/s10734-015-9979-2

Bicket, M., Misra, S., Wright, S. M., \& Shochet, R. (2010). Medical student engagement and leadership within a new learning community. BMC Medical Education, 10, 20. https:// doi.org/http://dx.doi.org/10.1186/1472-6920-10-20

Bovill, C. (2013). Students and staff co-creating curricula: A new trend or an old idea we never got around to implementing ? Improving Student Learning Through Research and Scholarship: 20 Years of ISL, (September). Oxford.

Bovill, C. (2014). An investigation of co-created curricula within higher education in the UK, Ireland and the USA. Innovations in Education and Teaching International, 51(1), 15-25. https://doi.org/10.1080/14703297.2013.770264

Bovill, C., \& Bulley, C. (2011). A model of active student participation in curriculum designexploring desirability and possibility. In C. Rust (Ed.), Improving Student Learning (18) Global theories and local practices: Institutional, disciplinary and cultural variations. (pp. 176-188). Oxford: The Oxford centre for staff and educational development.

Bovill, C, Cook-Sather, A., Felten, P., Millard, L., \& Moore-Cherry, N. (2016). Addressing potential challenges in co-creating learning and teaching: overcoming resistance, navigating institutional norms and ensuring inclusivity in student-staff partnerships. Higher Education, 71(2), 195-208. https://doi.org/10.1007/s10734-015-9896-4

Cook-Sather, A. (2015). Dialogue across differences of position, perspective, and identity: Reflective practice in / on a student-faculty pedagogical partnership program. Teachers College Record, 1-42.

Cook-Sather, A., Bovill, C., \& Felten, P. (2014). Engaging students as partners in learning and teaching: A guide for faculty (First; A. Cook-Sather, C. Bovill, \& P. Felten, eds.). San Francisco: Jossey-Bass.

Dickerson, C., Jarvis, J., \& Stockwell, L. (2016). Staff-student collaboration: Student learning from working together to enhance educational practice in higher education. Teaching in Higher Education, 21(3), 1-17. https://doi.org/10.1080/13562517.2015.1136279

Dolmans, D. H. J. M. (2019). How theory and design-based research can mature PBL practice and research. Advances in Health Sciences Education, 24(5), 879-891. https://doi. org/10.1007/s10459-019-09940-2

Fielding, M. (2011). Patterns of partnership: Student voice, intergenerational learning and democratic fellowship Rethinking Educational Practice Through Reflexive Research: Essays in Honour of Susan Groundwater-Smith Nicole Mockler and Judyth Sachs (eds) (2011).

Gibbs, G. (2010). Dimensions of quality. In International Journal. https://doi. org/10.1097/00005110-200109000-00006

Gravett, K., Kinchin, I. M., \& Winstone, N. E. (2019). 'More than customers': conceptions of students as partners held by students, staff, and institutional leaders. Studies in Higher Education, 45(12), 2574-2587. https://doi.org/10.1080/03075079.2019.1623769 
HEA NUS. (2011). Student engagement toolkit. Higher Education Academy and National Union of Students. Available from: www.nusconnect.org.uk/campaigns/highereducation/ student-engagement/toolkit/resources/

Healey, M., Flint, A., \& Harrington, K. (2014). Engagement through partnership: Students as partners in learning and teaching in higher education. The Higher Education Academy Report, (July), 1-76. https://doi.org/10.1080/1360144X.2016.1124966

Healey, M., \& Healey, R. L. (2019). Students as partners guide: Student engagement through partnership a guide to the advance HE framework student engagement through partnership.

Isaeva, R., Eisenschmidt, E., Vanari, K., \& Kumpas-Lenk, K. (2020). Students' views on dialogue: Improving student engagement in the quality assurance process. Quality in Higher Education, 26(1), 80-97. https://doi.org/10.1080/13538322.2020.1729307

Könings, K. D., Seidel, T., \& van Merriënboer, J. J. G. (2014). Participatory design of learning environments: Integrating perspectives of students, teachers, and designers. Instructional Science, 42(1), 1-9. https://doi.org/10.1007/s11251-013-9305-2

Matthews, K. E., Dwyer, A., Hine, L., \& Turner, J. (2018). Conceptions of students as partners. Higher Education, 76(6), 957-971. https://doi.org/10.1007/s10734-018-0257-y

Menon, S. T. (1999). Psychological empowerment: Definition, measurement, and validation. Canadian Journal of Behavioural Science, 31(3), 161-164. https://doi.org/http://dx.doi. org/10.1037/h0087084

Mercer-Mapstone, L., Dvorakova, S. L., Matthews, K. E., Abbot, S., Cheng, B., Felten, P., ... Swaim, K. (2017). A Systematic Literature Review of Students as Partners in Higher Education. International Journal for Students as Partners, 1(1), 1-23.

Moore-Cherry, N., Healey, R., Nicholson, D. T., \& Andrews, W. (2016). Inclusive partnership: Enhancing student engagement in geography. Journal of Geography in Higher Education, 40(1), 84-103. https://doi.org/10.1080/03098265.2015.1066316

Pierce, J. L., Kostova, T., \& Dirks, K. T. (2003). The state of psychological ownership: integrating and extending a century of research abstract. Review of General Psychology, 7(314), 1-35. https://doi.org/10.1037/1089-2680.7.1.84

Stevens, F., Wiltens, M. A., \& Koetsenruijter, K. (2010). The institutionalization of student participation curriculum evaluation: From passionate volunteers to skilled student delegates. In H. Van Berkel, A. Scherpbier, H. Hillen, \& C. Van der Vleuten (Eds.), Lessons from problem-based learning (pp. 177-184). Oxford: Oxford University Press.

Wildridge, V., Childs, S., Cawthra, L., \& Madge, B. (2004). How to Create Successful Partnerships - A Review of the Literature. Health Information and Libraries Journal, 21(Supplement 1), 3-19.

Williamson, M. (2013). Guidance on the development and implementation of a Student Partnership Agreement in universities. (November). Retrieved from http://www.sparqs. ac.uk/upfiles/Student Partnership Agreement Guidance - final version.pdf 

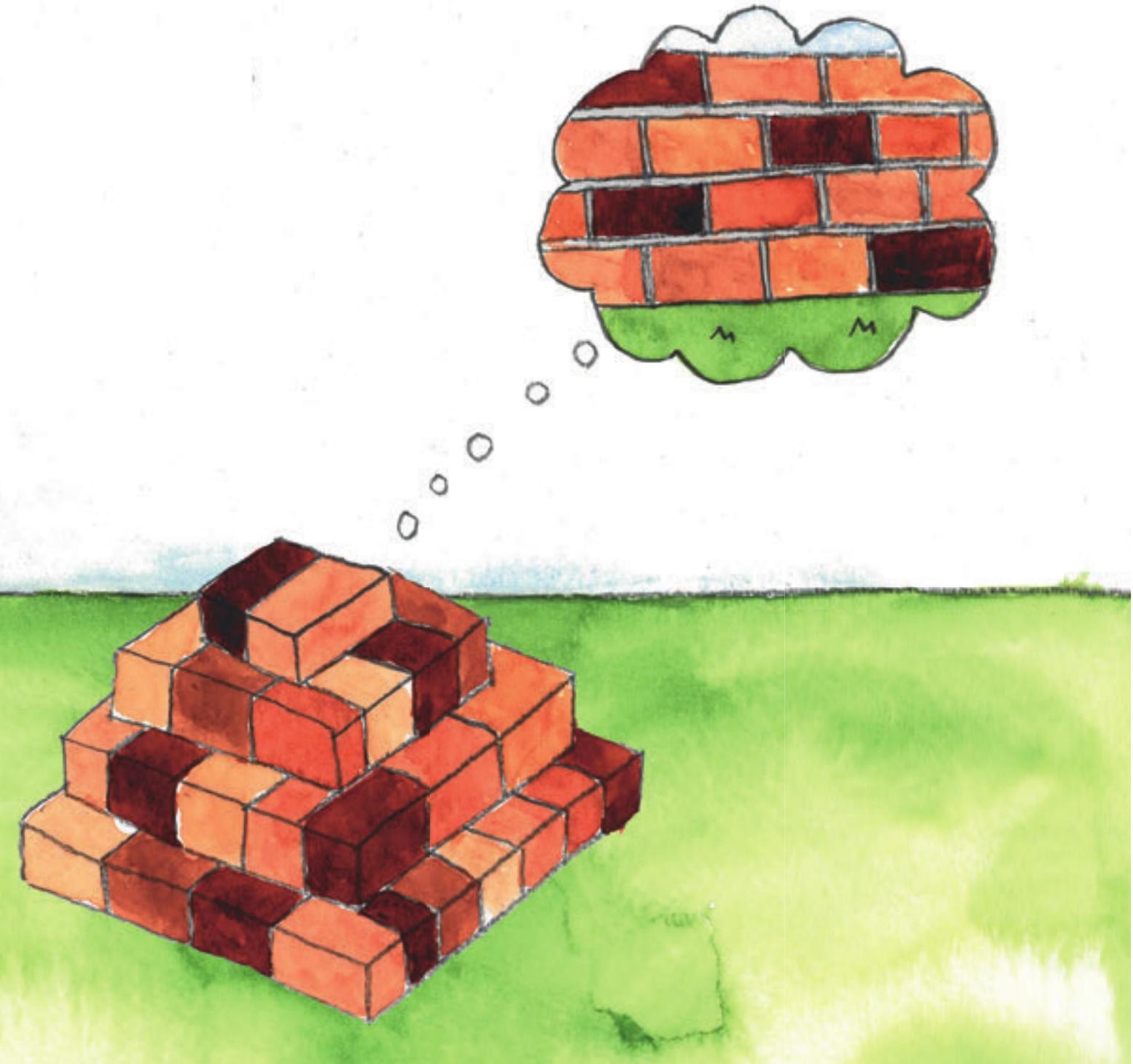


\section{Chapter 2}

\section{A students' take on student-staff partnerships: Experiences and preferences}

Martens, S. E., Spruijt, A., Wolfhagen, H. A. P., Whittingham, J. R. D., \& Dolmans, D. H. J. M. (2019). A students' take on student-staff partnerships: Experiences and preferences. Assessment and Evaluation in Higher Education, 44 (6), 910-919. 


\begin{abstract}
Students do not always feel that their ideas for improving educational quality are taken seriously. Student-staff partnerships may help take this feeling away. In such partnerships, students equally collaborate with staff and participate in shared decision-making and implementation processes for improving education. However, empirical research has hitherto paid scant attention to the question of how students experience such student-staff collaborations, whether they are willing to participate in these partnerships and, if so, under which circumstances. We therefore conducted an explanatory mixed-methods study, for which we administered a student-staff partnership questionnaire to 87 students and held four focus groups. In the students' view, students can provide a unique perspective on educational improvement. Yet, they did not consider their collaborations with staff as full partnerships, because their role remained restricted to giving advice and they were not involved in the implementation process. Although students felt respected by staff, they expressed a wish to be informed of what happened with their suggestions, and to be seen as equal partners while appreciating the difference in students and staff members' roles. Additionally, students pointed to a need for clear and well-communicated role descriptions. We conclude that to render student-staff partnerships effective, students should be empowered more.
\end{abstract}

\title{
Keywords
}

Quality improvement; student-staff partnership; student voice; higher education 


\section{Introduction}

Quality assurance systems have increasingly embraced student input as an essential quality marker (Cook-Sather 2009; Bovill 2013; Healey, Flint, and Harrington 2014; Moore-Cherry et al. 2016). It is widely agreed that students can make a valuable contribution to the improvement of education. Stevens, Wiltens, and Koetsenruijter (2010), for instance, have argued that students offer a unique perspective on educational improvement because they have first-hand experiences of education. Others have asserted that students can help raise the quality of education when they collaborate with staff (Könings, Seidel, and van Merriënboer 2014). Hence, it is clear that the value of student input is recognised by many. Nevertheless, this input has hitherto stayed largely confined to students filling in evaluation questionnaires and advising in focus groups (Giles et al. 2004), revealing a need for their deeper involvement in both the evaluation and implementation stages of educational improvement processes (e.g. Roberts and Nash 2009; Delpish et al. 2010; Blair and Noel 2014). At the same time, however, we see that the few students who are more deeply involved in course improvements do not always feel appreciated, respected, and valued (Bicket et al. 2010). In other words, student involvement is currently hampered by a prevalent feeling among students that their suggestions for improving educational practice are not always taken seriously.

Evidence from the literature demonstrates that it is possible for students and staff to collaborate on the improvement of education in all stages of the process, spanning both the course evaluation and implementation stages (e.g. Delpish et al. 2010; Cook-Sather, Bovill, and Felten 2014; Healey, Flint, and Harrington 2014; Bovill et al. 2016; Moore-Cherry et al. 2016). An example of such a promising collaboration is a student-staff partnership (Griffin and Cook 2009), which has been defined as 'a collaborative, reciprocal process through which all participants have the opportunity to contribute equally, although not necessarily in the same ways, to curricular or pedagogical conceptualization, decision-making, implementing, investigating or analysis' (Cook-Sather, Bovill, and Felten 2014, 6-7). This reciprocity is reflected in the act of students sharing their experiences and staff members contributing their expert knowledge. As such, these partnerships move beyond listening to students' voices, assigning a more active role to students, with both parties participating equally in both the decision-making and implementation stages of the improvement process (Williamson 2013). 
Although the ultimate aim of student-staff partnerships is clearly to improve educational courses/curricula (e.g. Cook-Sather 2010), research has demonstrated that they can also bring additional benefits in terms of improved meta-cognitive skills for students and transformed beliefs about teaching and teaching practices for staff (Cook-Sather, Bovill, and Felten 2014; Dickerson, Jarvis, and Stockwell 2016). Whether all of the aforementioned benefits can be reaped, however, depends on several criteria that should be met first. From the few empirical studies that have been conducted so far, we have learnt that successful studentstaff partnerships are based on: (1) reciprocal respect, (2) a feeling by students to be able to influence decision-making, (3) autonomy, (4) commitment, and (5) ownership/ responsibility (Cook-Sather, Bovill, and Felten 2014; Healey, Flint, and Harrington 2014). These criteria have been further explained in Table 1. A study by Bicket et al. (2010) has demonstrated that students are indeed willing to have more influence and be more respected.

Active student involvement in the form of student-staff partnerships is an exception rather than the rule (e.g. Bovill 2013). Moreover, most of what we know about student-staff partnerships comes from non-empirical studies. We therefore set out to collect empirical data about students' experiences of these partnerships and their associated preferences. More specifically, we sought to investigate the extent to which they felt the criteria for successful student-staff partnerships were met, whether they were willing to be engaged in such partnerships, and, if so, what their preferred conditions were. An answer to these questions can help us facilitate student-staff partnerships better and render them more successful. Specific research questions were:

1. To what extent do students experience their collaborations with staff as full partnerships and does the reality differ from their preferred situation?

2. Why and under which circumstances do students feel they can make a useful contribution in a student-staff partnership? 
Table 1.

Definitions of the five criteria for successful student-staff partnerships.

\begin{tabular}{|c|c|}
\hline Criterion & Definition \\
\hline Reciprocal respect & $\begin{array}{l}\text { Taking each other seriously, valuing each } \\
\text { other, and exchanging thoughts in an } \\
\text { equal manner (e.g. Cook-Sather et al. } \\
\text { 2014; Brandl, Mandel, and Winegarden } \\
\text { 2016) }\end{array}$ \\
\hline Influence & $\begin{array}{l}\text { Feeling that you can actually contribute } \\
\text { to educational improvement (e.g. Menon } \\
\text { 1999) }\end{array}$ \\
\hline Autonomy & $\begin{array}{l}\text { Determining by yourself how you will do } \\
\text { your job (e.g. Spreitzer 1995). }\end{array}$ \\
\hline Commitment & $\begin{array}{l}\text { Being willing to put extra effort into } \\
\text { improving education and being worried } \\
\text { about its quality (e.g. Bendermacher et al. } \\
\text { 2016). }\end{array}$ \\
\hline Ownership/responsibility & $\begin{array}{l}\text { Feeling that it is your job to improve the } \\
\text { educational system (e.g. Pierce, Kostova, } \\
\text { and Dirks 2003; Bendermacher et al. } \\
\text { 2016). }\end{array}$ \\
\hline
\end{tabular}

\section{Methods}

\section{Setting}

We conducted the present explanatory mixed-methods study at the Faculty of Health, Medicine and Life Sciences (FHML), Maastricht University, the Netherlands, where problem-based learning (PBL) is the dominant learning strategy. As a student-centred approach, PBL engages students actively in their own learning (van Berkel et al. 2010), by letting them discuss professionally relevant problems in small groups. Guided by a tutor, students actively participate in the group discussion and identify learning contents that need further study. After a period of self-study, students meet again to discuss what they have learnt.

\section{Participants}

Participants were students taking the undergraduate FHML programme in biomedical sciences, health sciences or medicine, including the international track. More specifically, these students were all actively involved in educational improvement as a member of: (1) A course design team in which staff meet to design or re-design a course and students (usually two per team) participate 
by giving staff feedback about issues that need improvement; (2) an evaluation panel in which students collect evaluative data about a course and discuss these data with staff; or (3) a curriculum or educational committee in which staff and students discuss issues related to the overall curriculum or specific courses in need of improvement. Within the FHML, a total of 135 undergraduate students from all years and programmes are actively involved in one of these activities. We invited all of these students to participate in the quantitative part of this study, to which 87 students responded positively (response rate of 64\%). The student sample consisted of 69 women aged between 18 and $24(M=20.96$, SD = 1.42), 17 men aged between 19 and $28(M=21.76, S D=2.49)$ and one who selected the neutral option. Twenty-five students ( 22 women; three men) participated in four additional focus groups.

\section{Instruments}

To answer our first research question, we invited students to fill in a questionnaire that we had specifically developed for this purpose. The student-staff partnership questionnaire (SSPQ) was based on insights from the existing literature about student-staff partnerships and associated criteria for success, and consisted of 26 items related to course improvement that were divided into the following five scales: Reciprocal respect (nine items), influence (three items), autonomy (three items), commitment (five items), and partnership (six items). We used Spreitzer's (1995) Psychological Empowerment Scale to measure 'influence' and 'autonomy'. Meyer, Allen and Smith's (1993) Affective Commitment Scale to gauge 'commitment' and developed our own scales to assess 'reciprocal respect' and 'partnership'. The items were related to course improvement. Students were asked to rate each item twice on a 5-point Likert scale ( 1 = strongly disagree, 5 = strongly agree): First to indicate their level of agreement as it applied to the present and then to indicate their preferred situation. Before administering the questionnaires, we tested them on four undergraduate students to make sure the items were clear and to record the time needed to complete the questionnaire.

We performed principal axis factoring (PAF) with orthogonal rotation, as the dataset resulted suitable for PAF based on the Kaiser-Meyer-Olkin (KMO) and Bartlett's test of sphericity: $\mathrm{KMO}=.78$; Bartlett's test of sphericity $\chi^{2}(465)$ $=1,594.46, p<.001$. Moreover, the questionnaire showed acceptable validity evidence and reliability, with Cronbach's Alphas ranging between .70 and .90 per 
factor. We considered a score below 3 as insufficient, a score above 4 as good and a score in between 3 and 4 as needing improvement.

To answer our second research question, we subsequently held four focus groups. In doing so, we first explained to students what we meant by studentstaff partnerships, before asking them several questions to gain insight into their experiences of the last academic year, such as: Would you like to be involved as partners in the improvement of education?; How and when can you have an influence?; Do you feel appreciated?.

\section{Procedure}

The research procedure consisted of two steps. First, we asked undergraduate student representatives to distribute the questionnaires by email to all students who were actively involved in educational improvement. Completed questionnaires were collected in the period between June and September 2017. Second, we conducted focus groups with students that had again been approached by the undergraduate student representatives by email. After we had conducted three focus groups, we noticed that students who were active in course design teams were underrepresented and therefore conducted a fourth focus group with course design team students only that we selected via purposive sampling. All focus groups were moderated by one of the authors (J.W.) and observed by the first researcher (S.M.) who took notes. Discussions were recorded, transcribed afterwards, and transcript summaries were made. We conducted a member check and all participants agreed on the transcript summaries. Focus group data were collected in the period between October and November 2017.

Before we administered the questionnaire and conducted the focus groups, students consented to participate in the study. We obtained ethical approval from the Ethical Review Board of the Netherlands Association for Medical Education (Ethical Review Board document number 896).

\section{Analyses}

We analysed the questionnaire data by calculating mean scores and standard deviations for each scale, reflecting students' current experiences of studentstaff partnerships and their associated preferences. To measure the differences between the present and preferred situation we ran bootstrapped paired $t$-tests 
with an a of .05. The bootstrapping assumption was met: The sample represented the population. In addition, we calculated Cohen's $d$ for each factor.

In the next step, we performed a template analysis of the focus-group transcripts, by following the 6-step procedure outlined in Brooks et al. (2015). This means that we: (1) Read the transcripts; (2) started preliminary coding guided by sensitising concepts; (3) organised emerging themes into relevant categories and defined the relationships between them; (4) decided on the initial template; (5) applied the template and adapted it as necessary; and (6) decided on the final template and applied it to all transcripts. Two authors created the initial template based on their coding of the first transcript, which they discussed afterwards to reach consensus. The first author coded the remaining three transcripts, while all members of the research team critically reviewed the final template and underlying themes.

\section{Reflexivity}

The first author has a background in educational sciences and was a student representative herself during her study programme. Consequently, she may have been positively biased towards student-staff partnerships. The other authors also have a background in educational sciences and have a special interest in evaluation and quality assurance as well as curriculum improvement. 


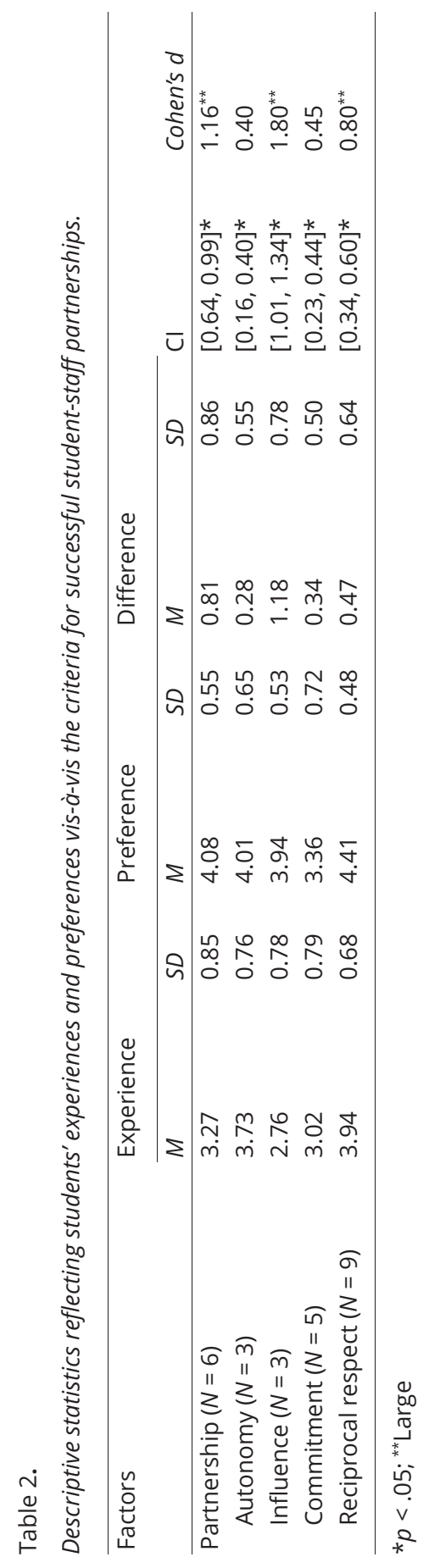




\section{Results}

\section{Questionnaire}

We found that, in students' experiences, students' scores of criteria for successful student-staff partnerships ranged from 3.02 (SD = 0.79) for commitment and 3.94 $(S D=0.68)$ for reciprocal respect. The mean score for influence was lower, being $2.76(S D=0.78)$. Students' mean rating of the partnership scale, reflecting their current experience of the same, was 3.27 (SD = 0.85).

Scores pertaining to students' preferences ranged from 3.94 (SD = 0.53) for influence to 4.41 (SD = 0.48) for reciprocal respect, with the exception of the mean score for commitment $(M=3.36$; SD $=0.72)$. The mean rating of the preferred situation of student-staff partnership was 4.08 (SD = 0.55).

As can be inferred from Table 2, students' experiences differed significantly from their preferences, with preference-related scores exceeding scores that reflected reality. This was particularly the case for the reciprocal respect, influence and partnership scales that had large effect sizes (>.80).

\section{Focus Groups}

From our template analysis of the focus-group transcripts, five main themes emerged: (1) Students offer a unique perspective, (2) students argue that staff members must be open to feedback, (3) students' involvement must include the implementation stage, (4) students and staff members' roles must be clearly defined and communicated, and (5) students must have prior experience of the course/organisation. While the first theme reflects students' view on why they felt they could make a useful contribution in a student-staff partnership, the other themes tell us what their preferred conditions are.

\section{Students offer a unique perspective}

With respect to the perceived value of students' contribution in student-staff partnerships, students repeatedly mentioned that they could offer a unique perspective on educational improvement. Consequently, they are motivated to participate in such partnerships. While appreciating staff members' content and didactic knowledge, students felt they could provide a different perspective, by putting forward new ideas and suggestions and performing a practicality check 
(checking whether something is feasible for students), which they considered a valuable addition:

Where, in my view, the student has a [very] important role to play is in, um, putting forward new ideas, new insights. Students [means staff] are sometimes just stuck, and therefore keep pursuing the same path. And you as a student can be the one who actually pushes that block into the right direction. (focus group 1)

[a student quoting a staff member] Really nice that you as students who are sitting there as representatives, came to us and told us this, because otherwise we would never have known. (focus group 1)

\section{Students argue that staff members must be open to feedback}

One of the most important obstacles to successful student-staff partnerships students encountered concerned staff members' receptivity to feedback. Although most staff members were open to feedback and conversations, there were still several instances in which students were confronted with staff members who were hesitant and not very receptive to feedback. Staff members' openness to feedback is crucial in developing good student-staff partnerships:

Like, in several courses they were really listening to us, and like, er, name it, name it, name it, we want to hear it, but sometimes they were just laughing our tips away. (focus group 2)

Sometimes you give feedback, and they just smile it away, and they were like, yeah, okay, we understand, but then in the end didn't ask questions to clarify things, and, you know, like, okay, ... that, not that receptive to your information. (focus group 2)

Yes, what really struck me was, it's, it's not just about them listening to you and taking you seriously, it is also really about them being open to changes. (focus group 1)

\section{Students' involvement must include the implementing stage}

Another reason why students did not experience their collaborations with staff as full partnerships was that they felt their influence was limited to giving advice. 
To reap the full benefits of partnerships, they felt they needed to be involved in all stages of the improvement process, from consultation to implementation. Although most staff members were open to students' improvement suggestions, they did not always clarify how they were going to incorporate them, nor did they explain to students when they chose not to act on them. Students understood that staff were busy, and that not all their suggestions could be taken up but would have appreciated being told the reasons for not doing so. Hence, improving courses together with students was not the norm yet, that is, it was not part of the existing culture. Moreover, students had the impression that improving and maintaining quality was not among the priorities of several staff members and students:

We've been stuck in the cycle of just giving them feedback, and not doing anything. (focus group 2)

Well, I think there is a difference between being heard, and that, than that changes are actually being implemented. So, like, yeah, we feel like they, they, they were heard, but nothing was changed afterwards, so, that's it. It's like, it was a good meeting, it was a productive meeting, but then I, I looked back a year later, and they still had the same courses, the teacher was the same and all, and so. (focus group 2)

\section{Students and staff members' roles must be clearly defined and communicated}

A third important condition for successful student-staff partnerships suggested by students was to have clear descriptions of students and staff's roles available and to effectively communicate these. Students felt they were not well-informed about their educational improvement roles and observed that students and staff members held different expectations of each other's roles. They also felt that staff members had too much freedom in deciding on the level of student involvement in improvement processes. As a solution, they suggested that they co-create role descriptions with staff members and that both students and staff members' roles be formalised. The need for clear role descriptions was felt less by students in management roles who, together with fellow students, were already regularly involved in decision-making processes. Moreover, their involvement was mandated by law or the institution, and hence their roles were already clearly 
defined. Although students in block-related roles advocated formalisation of roles, they did not want to lose the informal atmosphere. Moreover, they emphasised that their role was clearly distinct from staff members' in that the latter still need the final say:

I think it's also really important that the student knows what is expected of him or her. (focus group 4)

I think it would be really interesting if, um, students and staff would collaborate to write a job description so they could both, um, agree on the student's job. (focus group 4)

\section{Students must have prior experience of the course/organisation}

The final important condition that student-staff partnerships should meet according to students is that students must have knowledge or experience of blocks or the organisational structure. To be able to put forward valuable ideas, offer a different perspective and perform a practicality check, prior experience was indispensable:

But they're like really little but important, um, um, logistic things or something. You cannot, er, know about when you haven't taken the course. (focus group 4)

Yeah, I think it's really weird that you're a member of a ... course group and you haven't taken the course yet. Because [then] you really don't know what you're talking about. (focus group 4)

\section{Discussion}

The present article has sought to investigate how students experience student-staff partnerships, whether they are willing to participate in these partnerships, and, if so, under which circumstances. We have found that students indeed valued the existence of such partnerships, for they felt they could offer a unique perspective on educational improvement. Nevertheless, we also discovered that their preferred conditions for participating in such partnerships were not sufficiently met for several reasons. First, students felt that their influence was limited to giving advice and regretted that they were not involved in the implementation process. 
Consequently, they did not feel treated as partners in the true sense of the word. This was especially the case when staff members were not open to feedback or did not act on their suggestions. We may conclude that Deming's (1986) evaluation cycle of Plan-Do-Check-Act (1986) is not completed together with students (Becket and Brookes 2006), which can be considered a missed opportunity.

Students' discomfort may stem from the fact that students and staff members' roles not being clearly defined, nor communicated, resulting in a misalignment of mutual expectations. Despite prior research precisely underscored this need (Giles et al. 2004; Moore-Cherry et al. 2016), identifying open communication as key to the improvement of quality (Kleijnen et al. 2014), students and staff rarely discussed the specificities of their roles in their collaboration. Strikingly, however, students did not want to lose the informal atmosphere, which echoes Rice's (2002) assertion that preserving the informal atmosphere is crucial to developing relationships that are based on mutual trust. In a similar vein, our findings confirm Cook-Sather et al.'s (2014) conclusion that students should 'contribute equally, although not necessarily in the same ways' (7), a statement with which our students fully agreed. Finally, our findings tie in nicely with Bicket et al.'s ( 2010) observation that students wish to be empowered and appreciated more.

One of the strengths of the present study is that it adds to the small body of empirical evidence concerning student-staff partnerships through its use of a mixed-methods design. As such, it offers a deeper insight into the question of how students experience student-staff partnerships and what their preferred conditions are that can bolster the partnership's success.

Three limitations need addressing. First, because the study took place in a PBL setting, the findings may not be generalisable to other, non-PBL contexts in which students have a less active role in their own learning. In PBL settings, students already experience a high degree of involvement, which is due, in part, to small distances between students and staff members. Second, the study only explored students' perceptions of student-staff partnerships, while the perspectives of other stakeholders, such as staff members, may be equally worth investigating. Third, only students who were actively involved in educational improvement were included, even though regular students could be invited to take part in studentstaff partnerships as well. It is our contention that regular students at least deserve to be informed of improvements. Involving regular students was however out of the scope of the current study (Bicket et al. 2010).

In light of these limitations, we suggest that, before any student-staff partnerships 
are facilitated, more studies on these partnerships be conducted, preferably in other student-centred settings. We also invite future studies to investigate staff members' perceptions to gain a full picture of the opportunity to facilitate studentstaff partnerships. Their perspectives should not be overlooked. Finally, we welcome further research into the question of how we can extend the range of students involved in student-staff partnerships beyond those already involved in committees.

We propose that the questionnaire we used in this study be used in replications of our study in other settings. Our findings moreover underscore the need for clearly defined and well-communicated descriptions of students and staff's roles in student-staff partnerships. Not all students and staff can be involved in the same manner, so responsibilities of diverse students and staff members should be clearly spelt out. Finally, facilitation of student-staff partnerships could be enhanced if students and staff members received appropriate support in, for example, giving feedback or being involved in shared decision-making. We consider this a top priority.

In summary, our study sets out students' perceived conditions for successful student-staff partnerships, highlighting the importance of clearly defined improvement roles and student involvement in all stages of the process, including implementation. To render student-staff partnerships successful, students must be empowered first. 


\section{References}

Becket, N., and M. Brookes. 2006. "Evaluating Quality Management in University Departments." Quality Assurance in Education 14 (2): 123-42. doi:10.1108/09684880610662015.

Bendermacher, G. W. G., M. G. A. Oude Egbrink., I. H. A. P. Wolfhagen, and D. H. J. M. Dolmans. 2016. "Unravelling Quality Culture in Higher Education: A Realist Review." Higher Education. Springer Netherlands, 1-22. doi:10.1007/s10734-015-9979-2.

Berkel, H. Van., A. Scherpbier., H. Hillen, and C. Van der Vleuten. 2010. Lessons from ProblemBased Learning. Oxford: Oxford University Press.

Bicket, M., S. Misra., S. M. Wright, and R. Shochet. 2010. "Medical Student Engagement and Leadership within a New Learning Community." BMC Medical Education 10: 20. doi:http://dx.doi.org/10.1186/1472-6920-10-20.

Blair, E., and K. V. Noel. 2014. "Improving Higher Education Practice through Student Evaluation Systems: Is the Student Voice Being Heard?" Assessment \& Evaluation in Higher Education 39 (7): 879-94. doi:10.1080/02602938.2013.875984.

Bovill, C. 2013. "Students and Staff Co-Creating Curricula : A New Trend or an Old Idea We Never Got around to Implementing ?" Improving Student Learning Through Research and Scholarship : 20 Years of ISL, no. September: 96-108.

Bovill, C., A. Cook-Sather., P. Felten., L. Millard, and N. Moore-Cherry. 2016. "Addressing Potential Challenges in Co-Creating Learning and Teaching: Overcoming Resistance, Navigating Institutional Norms and Ensuring Inclusivity in Student-staff Partnerships." Higher Education 71 (2): 195-208. doi:10.1007/s10734-015-9896-4.

Brandl, K., J. Mandel, and B. Winegarden. 2016. "Student Evaluation Team Focus Groups Increase Students' Satisfaction with the Overall Course Evaluation Process." Medical Education, 51:215-227. doi:10.1111/medu.13104.

Brooks, J., S. McCluskey., E. Turley, and N. King. 2015. "The Utility of Template Analysis in Qualitative Psychology Research." Qualitative Research in Psychology 12 (2): 202-22. doi :10.1080/14780887.2014.955224.

Cook-Sather, A. 2010. "Students as Learners and Teachers: Taking Responsibility, Transforming Education, and Redefining Accountability." Curriculum Inquiry 40 (4): 555-75. doi:10.1111/j.1467-873X.2010.00501.x.

Cook-Sather, A. 2009. "From Traditional Accountability to Shared Responsibility: The Benefits and Challenges of Student Consultants Gathering Midcourse Feedback in College Classrooms." Assessment \& Evaluation in Higher Education 34 (2): 231-41. doi:10.1080/02602930801956042.

Cook-Sather, A., C. Bovill, and P. Felten (eds). 2014. Engaging Students as Partners in Learning and Teaching: A Guide for Faculty. San Francisco: CA: Jossey-Bass.

Delpish, A., A. Darby., A. Holmes., M. Knight-McKenna., R. Mihans, C. King, and P. Felten. 2010. "Equalizing Voices: Student-Faculty Partnership in Course Design." In Engaging Student Voices: In the Study of Teaching and Learning, edited by Carmen Werder and Megan Otis, 96-114. Sterling, VA: Stylus Publishing.

Deming, W. E. 1986. Out of the Crisis. Cambridge: Massachusetts Institute of Technology, Center for Advanced Engineering Study.

Dickerson, C., J. Jarvis, and L. Stockwell. 2016. “Staff-student Collaboration: Student Learning 
from Working Together to Enhance Educational Practice in Higher Education." Teaching in Higher Education 21 (3): 1-17. doi: 10.1080/13562517.2015.1136279.

Giles, A., S. C. Martin, D. Bryce, and G. D. Hendry. 2004. "Students as Partners in Evaluation: Student and Teacher Perspectives." Assessment \& Evaluation in Higher Education 29 (6): 681-85. doi:10.1080/0260293042000227227.

Griffin, A., and V. Cook. 2009. "Acting on Evaluation: Twelve Tips from a National Conference on Student Evaluations." Medical Teacher 31 (2): 101-4. doi:10.1080/01421590802225788.

Healey, M., A. Flint, and K. Harrington. 2014. “Engagement through Partnership : Students as Partners in Learning and Teaching in Higher Education." THe Higher Education Academy Report 21 (1) 84-86. doi:10.1080/1360144X.2016.1124966.

Kleijnen, J., D. Dolmans, J. Willems, and H. van Hout. 2014. “Effective Quality Management Requires a Systematic Approach and a Flexible Organisational Culture: A Qualitative Study among Academic Staff." Quality in Higher Education 20 (1). Routledge: 103-126. doi:10.1080/13538322.2014.889514.

Könings, K. D., T. Seidel, and J. J. G. van Merriënboer. 2014. "Participatory Design of Learning Environments: Integrating Perspectives of Students, Teachers, and Designers." Instructional Science 42 (1): 1-9. doi:10.1007/s11251-013-9305-2.

Menon, S. T. 1999. "Psychological Empowerment: Definition, Measurement, and Validation." Canadian Journal of Behavioural Science 31 (3): 161-164. doi:http://dx.doi.org/10.1037/ h0087084.

Meyer, J. P., N. J. Allen, and C. A. Smith. 1993. "Commitment to Organizations and Occupations: Extension and Test of a Three-Component Conceptualization." Journal of Applied Psychology 78 (4): 538-551. doi:10.1037/0021-9010.78.4.538.

Moore-Cherry, N., R. Healey, D. T. Nicholson, and W. Andrews. 2016. "Inclusive Partnership: Enhancing Student Engagement in Geography."Journal of Geography in Higher Education 40 (1): 84-103. doi:10.1080/03098265.2015.1066316.

Pierce, J. L., T. Kostova, and K. T. Dirks. 2003. “The State of Psychological Ownership: Integrating and Extending a Century of Research Abstract." Review of General Psychology 7 (314): 1-35. doi:10.1037/1089-2680.7.1.84.

Rice, E. H.. 2002. "The Collaboration Process in Professional Development Schools." Journal of Teacher Education 53 (1): 55-67. doi:10.1177/0022487102053001006.

Roberts, A., and J. Nash. 2009. "Enabling Students to Participate in School Improvement through a Students as Researchers Programme." Improving Schools 12 (2): 174-187. doi:10.1177/1365480209106590.

Spreitzer, G. M. 1995. "Psychological Empowerment in the Workplace: Dimensions, Measurement, and Validation." The Academy of Management Journal 38 (5): 1442-1465.

Stevens, F. M. A. Wiltens., and K. Koetsenruijter. 2010. "The Institutionalization of Student Participation Curriculum Evaluation: From Passionate Volunteers to Skilled Student Delegates." In Lessons from Problem-Based Learning, edited by H Van Berkel, Albert Scherpbier, H Hillen, and Cees Van der Vleuten, 177-84. Oxford: Oxford University Press.

Williamson, M. 2013. "Guidance on the Development and Implementation of a Student Partnership Agreement in Universities,". http://www.sparqs.ac.uk/upfiles/Student Partnership Agreement Guidance - final version.pdf. 


\section{Appendix A}

\section{Student-staff partnership questionnaire (SSPQ)}

\section{Reciprocal respect}

1. Staff members value the ideas I bring forward in an encounter.

2. Staff members appreciate my improvement suggestions.

3. Staff members seriously consider my input on educational improvements during the meetings.

4. Staff members seriously listen to my input on educational improvements.

5. Staff members and I have dialogues instead of one-way conversations.

6. My input on educational improvement is appreciated just as much as the suggestions of staff members are.

7. Staff members accept me, even when they disagree with my input on educational improvement.

8. Staff members' and my responses to each other's improvement suggestions are content-based.

9. I tell staff members with whom I collaborate in the blocks I am involved in when I think something is done wrong.

Influence ${ }^{a}$

10. I have significant influence over what happens in the blocks in which I am involved.

11. My impact on what happens in the blocks in which I am involved is large.

12. I have a great deal of control over what happens in the blocks in which I am involved.

\section{Autonomy $^{\mathrm{a}}$}

13. I have considerable opportunity for independence and freedom in how I do my job as an involved student.

14. I have significant autonomy in determining how I do my job as an involved student.

15. I decide on my own how to go about doing my work as an involved student.

\section{Commitment $^{\mathrm{b}}$}

16. I have a strong sense of belonging to the blocks I am involved in.

17. The blocks I am involved in have a great deal of personal meaning for me.

18. I feel emotionally attached to the blocks I am involved in.

19. I feel like being part of the family in the blocks I am involved in.

20. I set high quality goals for the blocks I am involved in and for which I am jointly responsible. ${ }^{c}$

\section{Partnership}

21. Staff members and I are collectively involved in the process of deciding on educational issues within the blocks.

22. Staff members and I collectively invent ways to carry out suggested educational improvements.

23. Staff members and I both agree on the decisions we made to improve education.

24. Staff members and I always discuss the different improvement suggestions together.

25. Staff members and I facilitate the implementation of suggested improvements together.

26. Staff members and I exchange ideas for educational improvement. 
${ }^{a}$ Copyright Psychological Empowerment Scale by Spreitzer, G. M. 1995. "Psychological Empowerment in the Workplace: Dimensions, Measurement, and Validation."

The Academy of Management Journal 38 (5):1442-1465. The scales were modified by S. E. Martens from the original scale.

${ }^{b}$ Copyright Affective Commitment Scale by Meyer, J. P., N. J. Allen, and C. A. Smith. 1993. "Commitment to Organizations and Occupations: Extension and Test of a Three-Component Conceptualization." Journal of Applied Psychology 78 (4):538-551. doi:10.1037/0021-9010.78.4.538. The scale was modified by S. E. Martens from the original scale.

'Copyright Psychological Ownership Questionnaire item by Avey, J. B, and B. J. Avolio. 2007. All rights reserved in all medium. Published by Mind Garden, Inc. www.mindgarden.com. The item was modified by S. E. Martens from the original item. 


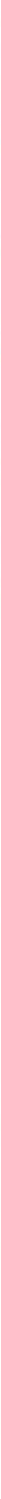




\section{Chapter 3}

\section{Student-staff partnerships for the}

broader student population

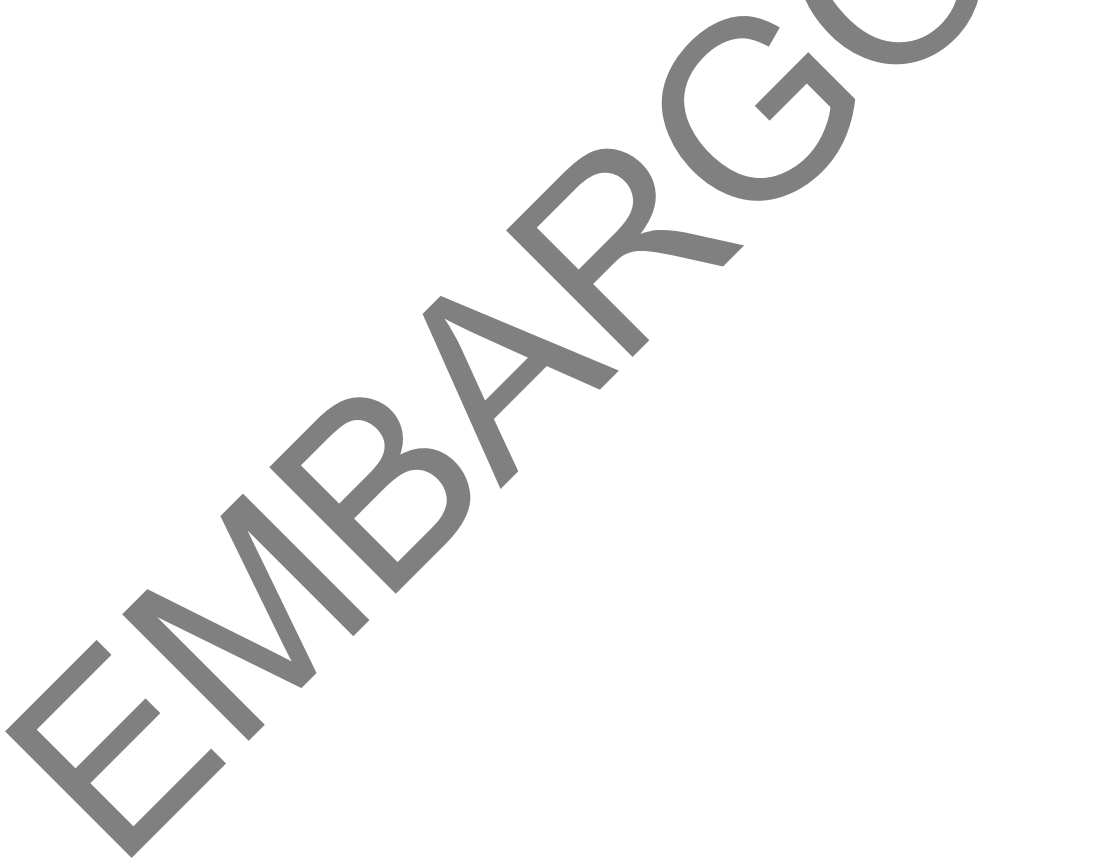

Martens, S. E., Wolfhagen, H. A. P., Whittingham, J. R. D., \& Dolmans, D. H. J. M. (2021). Student-staff partnerships for the broader student population. 


\section{Chapter 4}

\section{Behind the scenes -}

A path analysis of prerequisites for student-staff partnerships

Martens, S. E., Wolfhagen, H. A. P., Whittingham, J. R. D., \& Dolmans, D. H. J. M. (2021). Behind the scenes - A path analysis of prerequisites for student-staff partnerships. Submitted. 


\section{Chapter 5}

\section{Mind the gap: \\ Teachers' conceptions of student- staff partnership and its potential to enhance educational quality}

Martens, S. E., Wolfhagen, H. A. P., Whittingham, J. R. D., \& Dolmans, D. H. J. M. (2020). Mind the gap: Teachers' conceptions of student-staff partnership and its potential to enhance educational quality. Medical Teacher, 42(5), 529-535. doi: 10.1080/0142159X.2019.1708874 


\section{Abstract}

Introduction: Student-staff partnerships as a concept to improve medical education have received a growing amount of attention. Such partnerships are collaborations in which students and teachers seek to improve education by each adding their unique contribution to decision-making and implementation processes. Although previous research has demonstrated that students are favourable to this concept, teachers remain hesitant. The present study investigated teachers' conceptions of student-staff partnerships and of the prerequisites that are necessary to render such partnerships successful and enhance educational quality.

Method: We conducted semi-structured interviews with 14 course coordinators who lead course design teams and also teach in 4 bachelor health programmes, using Bovill and Bulley's levels of student participation as sensitising concepts during data analysis.

Results: The results pointed to three different conceptions of studentstaff partnerships existing among teachers: Teachers teach and students study; teachers teach and value students' feedback; and teachers and students co-create. The prerequisites for effective co-creation teachers identified were: Teachers must be open to involve students and create dialogues; students must be motivated and have good communication skills; the organisation must be supportive; and teachers should have the final say.

Conclusion: We conclude that teachers' conceptions are consistent with Bovill and Bulley's levels of student participation. Under certain conditions, teachers are willing to co-create and reach the highest levels of student participation.

\section{Keywords}

Roles of teacher; undergraduate; general; evaluation 


\section{Introduction}

Active student participation in improving medical education is of growing interest (e.g., ASPIRE Initiative 2012; Fujikawa et al. 2015; Peters et al. 2018; Martens, Meeuwissen, et al. 2019). Students can be actively involved in various ways, for instance by serving as student representative on advisory bodies or course design teams (Duffy and O'Neill 2003; Seale 2010; Bovill et al. 2011). Student participation has the potential to develop into a student-staff partnership (Delpish et al. 2010; Bovill and Bulley 2011). This can be defined as 'a collaborative, reciprocal process through which all participants have the opportunity to contribute equally, although not necessarily in the same ways, to curricular or pedagogical conceptualization, decision making, implementation, investigation or analysis' (Cook-Sather et al. 2014, p. 6-7). Evidence suggests that extensive collaboration between teachers and students in designing or redesigning teaching activities can further improve the quality of the instructional design and the resulting learning environment (Delpish et al. 2010; Könings et al. 2014). Student-staff partnerships create a context in which students and teachers each add their unique perspective on courses and share responsibility for teaching and learning (Dieter 2008; CookSather et al. 2014). When teachers and students have different conceptions of their roles, however, intensive collaboration may require considerable effort (Bovill et al. 2011).

A pertinent question worth addressing in this context is: What are teachers and students' conceptions of student-staff partnerships? Bovill and Bulley (2011) distinguished four levels of student participation, ranging from teachers being in control of decision-making processes, through teachers accepting student feedback to inform their decisions while still being in control, to students having a bit or considerable influence in the design process. Previous research into students' perspective has shown that students are willing to become involved in these partnerships (Bicket et al. 2010; Martens, Spruijt, et al. 2019). Among teachers, however, the idea of student-staff partnerships seems to find a less favourable reception (Bovill et al. 2016; Matthews et al. 2018). Research has demonstrated that teachers face several barriers to active student participation, such as the extra time it takes to involve students, the communication issues that arise, and students' lack of content expertise making teachers reluctant to empower students (e.g., Bovill et al. 2016). However, teachers' actual conceptions of these student-staff partnerships have hitherto not been fully explored. 
The aforementioned evidence leads us to believe that the success of student-staff partnerships is subject to certain conditions. Indeed, research has identified several prerequisites to establishing student-staff partnerships that in students' view are necessary, which are: Reciprocal respect, commitment of teachers and students, students must feel that they have influence and autonomy, clear communication between teachers and students about what they expect and students must have prior experience in a course (Martens, Spruijt, et al. 2019). Reciprocal respect refers to teachers and students treating each other as serious partners who can exchange thoughts equally (e.g., Cook-Sather et al. 2014; Brandl et al. 2017). Commitment is about teachers and students being willing to endeavour to improve courses (Bendermacher et al. 2017). Influence and autonomy go hand in hand, as students must feel that they are able to influence course improvement processes and that they have autonomy in deciding how to contribute (e.g., Healey et al. 2014). To meet the communication criterion mutual expectations must be clear (Andrews et al. 2013; Martens, Spruijt, et al. 2019). And finally, prior experience refers to the belief that students must have experienced a course before they are able to work in partnership to improve it (Martens, Spruijt, et al. 2019). Hence, it is clear which conditions must be fulfilled according to students. Although these are important insights, little empirical evidence exists on the prerequisites that teachers deem necessary to render such partnerships effective. The aim of the present study was therefore to investigate teachers' perceptions of the prerequisites for effective student-staff partnerships.

Student-staff partnerships are not yet common practice. When students and teachers establish a partnership, both parties must redefine their roles and responsibilities (Cook-Sather and Luz 2015). Teachers may feel that students lack the knowledge required for equal participation in course design and redesign, a conception that may make it difficult to establish a full partnership (Bovill et al. 2011). Hence, before we start implementing student-staff partnerships, it is imperative that we investigate how teachers feel about positioning students as partners in the revision of existing and the creation of innovative teaching practices. The current investigation seeks to answer the following two research questions: 
1. What are teachers' conceptions of student participation in improving educational quality?

2. What are teachers' conceptions of the prerequisites that are necessary to render student-staff partnerships effective and improve educational quality?

\section{Method}

\section{Setting}

The present qualitative study was set in a problem-based learning $(\mathrm{PBL})$ context. $\mathrm{PBL}$ is a student-centred approach to teaching in which students discuss relevant problems in groups of 10 students. A tutor facilitates the discussion, in which students identify learning needs that require attention during self-study. In the group meeting that follows, students discuss what they have learnt (Van Berkel et al. 2010).

We conducted this study at the Faculty of Health, Medicine and Life Sciences (FHML) of Maastricht University, the Netherlands, focusing on its four 3-year bachelor programmes in Medicine, Health Sciences, Biomedical Sciences and European Public Health. Students participate in the evaluation of courses by filling in end-of-course evaluation questionnaires. After each course, only those students who sit on the student evaluation panel meet once with the course coordinator to discuss the evaluation data and issues that need improvement; these students do not attend the meetings of the course design team. Course coordinators lead course design teams that consist of a multidisciplinary group of teachers including regular teaching staff who are responsible for the design, implementation, evaluation and continuous improvement of a course. In order to become a course coordinator, teachers must hold a PhD degree and a University Teaching Qualification (UTQ), as the UTQ programme pays attention to curriculum design. Although course coordinators can hold an MD degree, they are not required to, nor do they need to be expert at all course contents. Not only are course coordinators involved in the design and general organisation of a course, they also teach: They guide tutorial groups, provide lectures, and are involved in the assessment. In this position, they are the ones who have most contact with students about educational improvement. Course coordinators may choose to collaborate with students in their course design teams, by asking their input on aspects of the course that need improvement. Maastricht University affords students the opportunity to fill in evaluation questionnaires and to participate in an evaluation panel or course design team. 


\section{Participants}

Participants were 14 course coordinators of the four aforementioned bachelor programmes. For ease of reference, we will refer to these coordinators as 'teachers'. From the 37 applications received, we selected participants until we reached theoretical saturation, making sure to achieve an even distribution among the programmes and a variegated range of experience in years. Two teachers whom we approached did not participate in the study since they were on sabbatical. As a result, our sample included four teachers of Biomedical Sciences, four teachers of European Public Health, three teachers of Health Sciences and five teachers of Medicine including the international track. Five teachers were women; nine were men. Eight teachers coordinated a course in the first year, seven in the second year and three teachers coordinated a course in the third year of the curriculum. The participant numbers do not add up to 14 , since four teachers coordinated multiple courses. The participants had between 3 and $15(M=8.00 ; S D=3.97)$ years' experience as a teacher when they participated in the interview.

\section{Interview guide}

The first author (SM) conducted the interviews, during which she first explained to the teachers what the researchers meant by 'student-staff partnerships'. Drawing from Cook-Sather et al.'s work (2014), we defined these partnerships as: 'Students and teachers designing or redesigning education together by contributing equally to decision-making and course improvement processes. In doing so, students and teachers respect each other and are equal partners, although their input may differ'. Questions asked to address research question 1 included: 'How do you currently involve students in decision-making processes related to educational improvement?' And to answer research question 2: 'What do you need to involve students in educational decision-making and improvement processes?' For the interview guide that contains the interview questions, see Supplementary Appendix A. Additionally, we provided participants with vignettes of definitions of the prerequisites for student-staff partnerships known to date to help explore potential answers to research question 2 (see Supplementary Appendix B). We asked teachers what they needed to meet these criteria. 


\section{Procedure}

We conducted individual, semi-structured interviews that lasted for approximately $1 \mathrm{~h}$ each. Data collection took place over a period of 8 weeks. Teachers provided their consent before the start of the interview. The interviews were recorded and transcribed afterwards. Prior to analysing the data, all participants verified and agreed on the one-page summary of their interview transcript (member check). Three participants made minor modifications to improve clarity, without changing the content. The Ethical Review Board of the Netherlands Association for Medical Education provided ethical approval for this study (Ethical Review Board Number 1035).

\section{Analysis}

To capture the underlying mechanisms of teachers' conceptions of student-staff partnerships, we performed a template analysis of the qualitative data following the six-step procedure described by Brooks et al. (2015). We used this form of thematic analysis as we already had a priori themes in mind. First, SM listened to the audio files, read the transcripts, and made summaries to get to know the data. Secondly, our approach to analysing the data was both inductive and deductive: On the one hand, we used Bovill and Bulley's (2011) levels of student participation in curriculum design and prerequisites of students' perspective as a lens to explore the data (deductive), while on the other hand we used teachers' terminology and words to guide our analysis (inductive). Two authors (SM and JW) independently did the initial coding of one transcript, discussing their findings within $2 \mathrm{~h}$ afterwards to reach consensus. Despite differences in the level of detail, codes were similar. We coded all aspects that were relevant to answer the research questions. Thirdly, SM created a hierarchical structure, by clustering codes into themes and identifying relationships among them. Fourthly, SM and JW created and discussed the initial template based on the previous steps. Fifthly, the research team adapted the initial template by restructuring the themes during three discussion sessions. This was an iterative process. All authors critically reviewed the themes and schematic overview. During the discussion meetings, they all saw parts of the data and made changes by re-clustering and relabelling the codes. Finally, the research team developed the final template together. SM applied the final template to the remaining transcripts and verified whether it 
also fitted all previous transcripts. Throughout this process, we used software programme NVivo to manage the interview data.

\section{Reflexivity}

All authors have a background in educational sciences and take an interest in evaluating and improving educational quality. The authors were aware of their positive stance towards student participation and therefore made a deliberate effort to adopt a neutral perspective during data analysis.

\section{Results}

In the following, we will first present the themes we constructed from our data, representing teachers' different conceptions of student-staff partnerships. Next, we describe the prerequisites that, in the eyes of teachers, are necessary for the success of these partnerships. Finally, Figure 1 provides an overview of these conceptions and prerequisites.

\section{Teachers' Conceptions of Student-Staff Partnerships}

Based on the interviews we identified three different conceptions of student-staff partnerships, which are: (1) Teachers teach and students study, (2) Teachers teach and value students' feedback and (3) Teachers and students co-create teaching and learning.

\section{Teachers teach and students study}

During the interviews, when we asked teachers to describe their conceptions of student-staff partnerships, a few teachers expressed their concerns about actively involving students in the design of their course. They argued that students could not easily be a substitute for the wealth of experience and knowledge they had gained over the years. More specifically, they felt that students and teachers served different purposes: Students are at university to learn, while teachers are at university to teach. As they believed that improving courses was their core task, they distanced themselves from involving students in course design, both content-wise and pedagogical/didactic-wise. Similarly, involving students in course redesign would have limited effects in their view, since students lack knowledge in this regard. Even student feedback on end-of-course evaluation questionnaires 
in some cases would not be relevant and should therefore not be taken seriously, these teachers concluded:

The student is here to learn, a teacher is here to, er, to teach. That is the task that has been agreed upon. - Participant 13

They [students] are sometimes in a situation in which their personalities are not fully developed. They are still very young. And they lack certain experience. - Participant 6

\section{Teachers teach and value students' feedback}

The majority of the interviewees perceived a student-staff partnership as a collaboration in which students shared experiences with a course from which teachers could benefit when improving or redesigning the course. A proactive attitude towards the involvement of students in evaluation and openness to student feedback was common among this group. Teachers valued end-of-course evaluations and focus-group sessions in which students evaluated the course. In improving courses, they took students' advice into account and valued students' unique contribution for its ability to explain how they had experienced the course. In their view, student-staff partnership was about inviting students at the end of the course to provide feedback and think along. Nevertheless, these teachers were not always aware that they could involve students more than they were doing, for instance in the redesign of a course. When asked if students could also be involved in course redesign, teachers were rather open to this idea and saw added value, although they had not initially mentioned this and had no experience so far. We also observed that teachers related their openness to student participation to their own experiences as students:

Er, I think it is always important to involve students to, er, receive feedback, [to incorporate] them as a sounding board. - Participant 11

In the past, I have always been able to say my piece, when I wanted to. As a student, I also served on the programme committee. And it was also important to me that [they] listened to us and that [they] took me seriously. That feeling of the past that you were taken seriously when you contributed something, I think, yes, that now just passes on to me as a teacher. - Participant 3 


\section{Teachers and students co-create teaching and learning}

From the interviews, it was clear that some teachers perceived student-staff partnerships as involving students in the design or redesign of courses in collaboration with teachers. By student-staff partnership they meant including students as equal partners in discussions about which aspects of a course needed improvement. In addition, they believed that students and teachers could cocreate courses and gave students opportunities to take the initiative. For instance, they developed the initial learning task or assessment, but allowed students to improve this task or assessment using track changes or they even invited students to design a learning task or assessment and then finalised it by providing their own feedback. In their view, involving students in course redesign would not only benefit students and teachers alike, it would also raise the quality of the course. Because of their experience in the course, students could make a unique contribution and introduce new ideas. That is, they could suggest additional content and teaching methodologies as they sometimes read new articles and experienced new educational methods during other courses. They considered this unique contribution to be of key value in educational design or redesign: Courses would become more aligned with students' preferences and capabilities; and students would likely become more motivated when involved in course redesign, potentially leading to a better understanding and increased competencies. For these reasons, these teachers regarded course co-creation with students as highly beneficial for all parties, both students and teachers:

I think that there are many different educational formats that are more appealing to students and we have ideas about that. However, I do not have all the answers and when students have interesting ideas they have acquired maybe elsewhere, at other educational programmes, heard from friends, acquaintances, I do not know. List them, I think then you have to talk about it. - Participant 7

At a certain point, a student asked me about it [content-related topic] and I knew, I was lost for words. This happened a few years ago and I really did not know it. And then I started researching and it turned out that the student was more up to date than I was. - Participant 5 


\section{Teachers' perceived prerequisites for student-staff partnerships}

Teachers indicated that several prerequisites were necessary for the successful establishment of a student-staff partnership in which both parties contribute equally, although each with their unique contribution, to the creation or redesign of a course. The prerequisites mentioned were: (1) Teachers must be open to involve students and be aware of the possibility; (2) Teachers and students must have dialogues to explore their perspectives equally; (3) Students must be motivated and able to communicate in a constructive manner; (4) The organisation must be supportive; and (5) Teachers should have the final say.

Teachers must be open to involve students and be aware of the possibility

According to our participants, teachers must be open to involve students, since openness is a basic attitude for change. When teachers are approachable, students will more readily provide their input. We also observed, however, that not all teachers were aware of the possibility to involve students more deeply in course improvement processes:

Yes, I think that we um. but then you should be open to it and that is one of the prerequisites, it is. A really important prerequisite. If we are, I think that we would be able to come closer to students' experience. We really do not have a clue I guess. Er, and what their experience looks like. - Participant 3

\section{Teachers and students must have dialogues to explore their perspectives equally}

A second prerequisite to which participants attached importance was that students and teachers must have dialogues in which their perspectives are equally appreciated. Teachers explained that when students are treated equally, they will feel more respected and taken seriously. Consequently, they will provide input that is more valuable and advance powerful arguments to reach consensus. In this process, trust is key, as sensitive information such as teacher manuals could be the topic of discussion; teachers must be able to trust that students will not pass the teacher manual on to other students: 
No, I mean, we live in 2018 and we do not live in 1956 anymore where a professor was superior to students. No, I think there should be a certain level of equality, that, that would be interesting. - Participant 7

Those are my course design team members. They are considered as equally appreciated partners. And we take decisions by mutual agreement... And sometimes people agree and sometimes people disagree... And that is, it does not matter in this case whether the course design team member is a teacher or a student. Yes, it is discussed, different perspectives are taken into account. In this case, everyone agreed in the end. - Participant 3

\section{Students must be motivated and able to communicate in a constructive manner}

Teachers pointed to students being highly motivated and having good communication and collaboration skills as vital prerequisites, because only motivated students could add value to an encounter. They argued that most students were more concerned with assessments than with improving education; their primary aim was to pass their assessments. Teachers believed that if students participate as partners, they must also be motivated to gain experience in higher education, content knowledge and knowledge on how to construct a course. Moreover, students must be able to communicate in a proper way. The need for good communication skills in student-staff partnerships had two reasons: (1) Teachers did not want to become insecure due to students' input, and (2) teachers wanted to receive and understand students' input and avoid that students remained silent:

Well yes, I think that it should be an intrinsically motivated student. And a student who is not ... yes, it should be a team player. If the student is not a team player, but again yes, er, those are competencies we all focus on. Communicator, collaborator... yes, if he cannot do that, we should not start with it. - Participant 10

Well, you have training sessions that we as teachers could, er, do. They concern course development. Er.. I have done the UTQ [University Teaching Qualification] course, for example. So that might be too much for a student, but I think that there are parts ... [so] that a student could roughly get the idea: okay, this is how we develop a curriculum, how a course is developed, er. - Participant 12 


\section{The organisation must be supportive}

A fourth criterion participants raised was that the organisation must facilitate a shift from a 'student as passive consumer' conception towards a 'student as partner' conception, by promoting changes in systems and culture towards this latter conception. In doing so, it must reward all stakeholders for the effort they put into building student-staff partnerships. For instance, the organisation could recognise students' help in redesigning education as an extracurricular activity by assigning additional credits; or it could include a remark in students' diploma, so that students could list the activity in their Curriculum Vitae; or give them a financial compensation. Some teachers were also concerned about the time it would take them to involve students in the design of a course, although other teachers argued that the workload would enhance first as students need support, but would decrease in the long run when less support is needed:

What I would like to indicate is that you have the management, er, they should agree on these kinds of educational improvements, because if they are obstructive. Yes, er then it fails. Guaranteed. - Participant 8

I won't find any surgeon prepared to do that [student-staff partnerships] like that, for nothing. Because then they will need to block an outpatients', which will cost them. It means that they will see less patients. I won't be able to accomplish that. - Participant 4

\section{Teachers should have the final say}

Teachers explained that to make partnerships work, only they should have the final say in decision-making and implementation processes. The arguments they put forward were two: First, they must justify to higher management why a course went well (or not) and students cannot take over this role. Secondly, students lack the ability to have a say in such processes because they would only include topics in instructional redesign that are of interest to them instead of the topics needed to become a professional. More specifically, teachers felt that students did not have an overview of the work field and were therefore not informed of the knowledge that is required to become a professional: 
You are responsible for it. So that implies making adaptations to a course, but as well, whether you provide a question for assessment, in that case someone can contribute to making such a question, but you are in charge of the final editing. - Participant 2

The course coordinator is responsible ... and if ... a student [joins] an equally appreciated partnership, but without the responsibility, something does not add up. ... Well, because if a student's input is equal and [his/ her ideas] are implemented, but then [this student] is not responsible for it and it goes wrong... The course coordinator takes the rap. That is not possible. - Participant 13

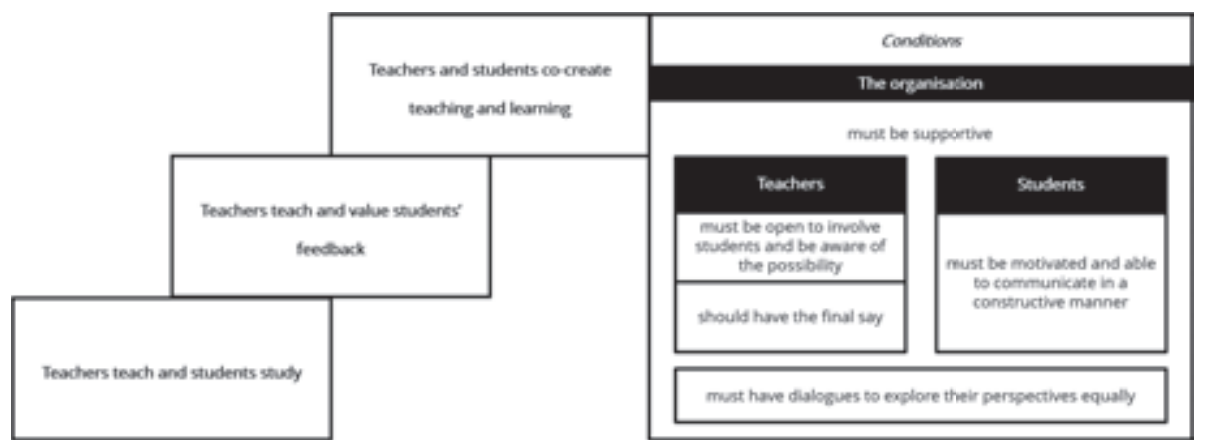

Figure 1. An overview of teachers' conceptions of student-staff partnerships and of the prerequisites that are necessary to render co-creation in teaching and learning by teachers and students successful.

\section{Discussion}

The purpose of the present study was to enhance our understanding of teachers' conceptions of student-staff partnership and of its prerequisites for improving educational quality. Teachers' conceptions differed from believing that students should have limited space in course redesign, through valuing students' feedback on how to improve courses, to feeling that students and teachers can co-create and redesign courses. Some teachers were of the opinion that teachers and students have different goals within the university, that is, teachers teach, while students learn and seem to lack knowledge. Other teachers felt that teachers teach but should also take students' feedback into account, and yet others believed that students and teachers can contribute equally to discussions aimed at the co-creation or redesign of education. According to teachers, co-creation seems 
attainable when both students and teachers are motivated, able to communicate, willing to have dialogues to explore each other's unique perspectives and learn about each other's experience, and when teachers have the final say. Finally, they argued that the organisation must support the development of this process.

Our conclusions related to our first research question confirm previous research by Bovill and Bulley (2011) who demonstrated that student participation can take place on multiple levels, from students having hardly any influence to students having significant influence. The present study contributes to this distinction by embedding student participation levels in empirical evidence and by explaining why teachers have these different conceptions of student participation. Teachers who believe that teachers and students serve different purposes in education (the 'teachers teach and students study' conception) are likely to exclude students from educational improvement discussions for they expect little from students' input. By contrast, teachers who feel that students can provide valuable feedback (conception 2) will likely use their feedback to improve education. And finally, teachers who believe in the benefits of students and teachers co-creating education (conception 3) are likely to form partnerships in which students and staff collaborate and learn from each other with the aim to transform and improve education. What is notable is that the conceptions we identified are part of a continuum, as teachers indicated a willingness to change their views. This resonates with the idea put forward by Griffin and Cook (2009) who stated that teachers can switch from using student feedback towards reaching partnerships.

As to our second research question about teachers' conceptions of the prerequisites for student-staff partnerships, we found that teachers partly shared students' view exposed by a previous study (Martens, Spruijt, et al. 2019) that reciprocal respect and communication are vital to making student-staff partnerships work. That is, teachers believed that students' input would become more valuable if they respected students and treated them equally. If both students and teachers communicate in a good, respectful manner, both students and teachers would feel safe to share their thoughts. Moreover, both studies concluded that, sadly, students' role still seems to be restricted to giving advice. Strikingly, our study also found that teachers feel that the final say should be theirs, which conception seems to be at odds with the definition of partnership implying that students and teachers have the opportunity to contribute equally. Consequently, such conception could pose an obstacle to achieving full partnerships. The fact that even the teachers 
upholding the 'teachers and students co-create' conception felt that they should have the final say and responsibility indicates some resistance to student-staff partnerships. A reason could be that teachers feared that empowering students in this way would create a situation in which they had less power than students, a fear that is not justified, however (Cook-Sather et al. 2014; Bovill et al. 2016; Matthews et al. 2018). A question that could be raised is: If teachers and students do not share the final responsibility, can they truly contribute equally?

A note of caution might be that this study reports on the conceptions of course coordinators only. Although we selected these coordinators purposefully because they had the most contact with students who are actively involved, the scope of this study could be extended to include other stakeholders, such as regular teaching staff, managers and regular students. To overcome resistance to implementation, future studies could focus on the role of these stakeholders (Burnes 2015). Another limitation of the present study is that it could partly be biased towards more positive conceptions since the study took place in a PBL context in which teachers and students already have a close connection and students are already actively involved in their own education. We therefore welcome replications of our study in other settings. Additionally, we invite researchers to explore the relationship between course evaluation results and teachers' conceptions of student participation.

Our findings underscore the fact that establishing student-staff partnerships requires effort. Evidence of the prerequisites necessary for successful studentstaff partnerships will only be useful when both teachers and students support them. The teachers in our study made several practical suggestions on how to improve such support. For instance, we could let teachers who are already open to active student participation act as role models: If their colleagues witness studentled improvements and how they let students participate, they might appreciate the benefit of student-staff partnerships. Also, we could select new teachers according to not only their knowledge and experience, but also their willingness to involve students in educational improvements. At the same time, we could introduce informal student job interviews such as speed dating to guarantee that students are highly motivated and have good communication skills. Finally, to ensure a supportive organisation, teachers suggested changing the structure by appointing more students to course design teams or letting students design a course or a training. We recommend that targeted interventions be developed to 
facilitate student-staff partnerships that take not only students' perspective, but also teachers' perspective into account. In doing so, the insights from this study into the three conceptions of teachers could serve as an important starting point.

\section{Conclusion}

The present study has revealed teachers' different conceptions of student participation and of the prerequisites that are necessary to render student-staff partnerships successful. Although equality in the final say may be a bridge too far, teachers are willing to co-create courses with students.

\section{Practice Points}

- Teachers' conceptions of student-staff partnerships were three: Teachers teach and students study; teachers teach and value students' feedback; and teachers and students co-create teaching and learning.

- According to teachers, to reach co-creation, teachers must be open to involve students and create dialogues; students must be motivated and be able to communicate; the organisation must be supportive; and teachers should have the final say. 


\section{References}

Andrews A, Jeffries J, St Aubyn B. 2013. By appointment to Birmingham City University students: Promoting student engagement through partnership working. In Nygaard C, Brand S, Bartholomew P, Millard L, editors. Student engagement: Identity, motivation and community. Oxfordshire: Libri Publishing; p. 199-212.

ASPIRE initiative: International Association for Medical Education in Europe. 2012. [accessed 2019 Apr. 8]. https://www.aspire-to-excellence.org/Areas+of+Excellence/

Bendermacher GWG, Oude Egbrink MGA, Wolfhagen, IHAP, Dolmans DHJM. 2017. Unravelling quality culture in higher education: a realist review. High Educ. 73(1):39-60.

Bicket M, Misra S, Wright SM, Shochet R. 2010. Medical student engagement and leadership within a new learning community. BMC Med Educ. 10(20):1-6.

Bovill C, Bulley C. 2011. A model of active student participation in curriculum design-exploring desirability and possibility. In: Rust C, editor. Improving Student Learning (18) Global theories and local practices: Institutional, disciplinary and cultural variations. Oxford: The Oxford centre for staff and educational development; p. 176-188.

Bovill C, Cook-Sather A, Felten, P. 2011. Students as co-creators of teaching approaches, course design, and curricula: implications for academic developers. Int J Acad Devel. 16(2): 133-145.

Bovill C, Cook-Sather A, Felten, P, Millard L, Moore-Cherry N. 2016. Addressing potential challenges in co-creating learning and teaching: overcoming resistance, navigating institutional norms and ensuring inclusivity in student-staff partnerships. High Educ. 71(2): 195-208.

Brandl K, Mandel J, Winegarden B. 2017. Student evaluation team focus groups increase students' satisfaction with the overall course evaluation process. Med Educ. 51(2): 215227.

Brooks J, McCluskey S, Turley E, King N. 2015. The Utility of Template Analysis in Qualitative Psychology Research. Qual Res Psychol. 12(2): 202-222.

Burnes B. 2015. Understanding resistance to change - Building on Coch and French. J Change Manag. 15(2): 92-116.

Cook-Sather A. 2014. Multiplying perspectives and improving practice: What can happen when undergraduate students collaborate with college faculty to explore teaching and learning. Instr Sci. 42(1): 31-46.

Cook-Sather A, Bovill C, Felten P. 2014. Engaging students as partners in learning and teaching: A guide for faculty. San Francisco (CA): Jossey-Bass.

Cook-Sather A, Luz A. 2015. Greater engagement in and responsibility for learning: what happens when studetns cross the threshold of student-faculty partnership. High Educ Res Dev. 34(6):1097-1109.

Delpish A, Darby A, Holmes A, Knight-McKenna M, Mihans R, King C, Felten, P. 2010. Equalizing voices: student-faculty partnership in course design. In Werder C, Otis M, editors. Engaging student voices: in the study of teaching and learning. Sterling (VA): Stylus Publishing; p.96-114.

Dieter PE. 2008. Quality management of medical education at the Carl Gustav Carus Faculty of Medicine, University of Technology Dresden, Germany. Ann Acad Med Singapore. 37(12): 1038-1040. 
Duffy KA, O'Neill PA. (2003). Involving medical students in staff development activities. Med Teach. 25(2): 191-194.

Fujikawa H, Wong J, Kurihara H, Kitamura K, Nishigori H. 2015. Why do students participate in medical education? Clin Teach. 12(1): 46-49.

Healey M, Flint A, Harrington K. 2014. Engagement through partnership : students as partners in learning and teaching in higher education. York: The Higher Education Academy. https:// www.heacademy.ac.uk/system/files/resources/engagement_through_partnership.pdf

Könings KD, Seidel T, Van Merriënboer JJG. 2014. Participatory design of learning environments: Integrating perspectives of students, teachers, and designers. Instr Sci. 42(1):1-9.

Martens SE, Meeuwissen SNE, Dolmans DHJM, Bovill C, Könings KD. 2019. Student participation in the design of learning and teaching: Disentangling the terminology and approaches. Med Teach. 41(10):1203-1205.

Martens SE, Spruijt A, Wolfhagen IHAP, Whittingham JRD, Dolmans DHJM. 2019. A students' take on student-staff partnerships: experiences and preferences. Assess Eval in Higher Educ. 44(6):910-919.

Matthews KE, Dwyer A, Hine L, Turner J. 2018. Conceptions of students as partners. High Educ. 76(6):957-971.

Peters H, Zdravkovic M, João Costa M, Celenza A, Ghias K, Klamen D, Weggemans M. 2018. Twelve tips for enhancing student engagement. Med Teach. 41(6):632-637.

Seale J. 2010. Doing student voice work in higher education: An exploration of the value of participatory methods. Brit Educ Res J. 36(6):995-1015.

Van Berkel H, Scherpbier A, Hillen H, Van der Vleuten C. 2010. Lessons from problem-based learning. Oxford: Oxford University Press. 


\section{Appendix A}

\section{Interview guide}

\section{Introductory question}

1. Introduce yourself

- Course/year of the undergraduate programme

- Years of experience as course coordinator

\section{Transition question}

1. Describe how you, as the course coordinator, collaborate with students to improve education.

\section{Student-staff partnership}

Students and teachers designing or redesigning education together by contributing equally to decision-making and course improvement processes. In doing so, students and teachers respect each other and are equal partners, although their input may differ.

\section{Key questions}

1. What do you think of this idea? Why is it a good idea/why not?

2. How do you currently involve students in decision-making processes related to educational improvement and how do you involve students in facilitating implementation processes?

3. What do you see as advantages and disadvantages of student-staff partnerships?

4. What do you need to involve students in decision-making processes and in the creation of education?

5. What do students need before they can be involved in decision-making processes and in the creation of education? 
Students' perceived prerequisites for student-staff partnerships known to date

- Reciprocal respect

- Influence/autonomy (empowerment)

- Commitment

- Communication

- Prior experience

6. What do you think of this definition?

7. How can we reach this?/ How did you reach this?

Wrap-up question

1. Do you want to discuss a topic that we have not discussed yet? 


\section{Appendix B}

\section{Vignettes or definitions of students' perceived prerequisites for} student-staff partnerships known to date

\section{Partnership}

Students and teachers designing or redesigning education together by contributing equally to decision-making and course improvement processes. In doing so, students and teachers respect each other and are equal partners, although their input may differ.

\section{Reciprocal respect}

Taking each other seriously, appreciating each other and exchanging thoughts in an equal way during decision-making processes.

\section{Influence/autonomy}

Being able to actually contribute to educational improvement processes and being free to decide on how to contribute.

\section{Commitment}

Willing to put extra effort into improving education and being concerned about the quality.

\section{Communication}

Ensuring that all mutual expectations are clear.

Prior experience

The need to have experienced a course before being able to make a relevant contribution to its improvement. 


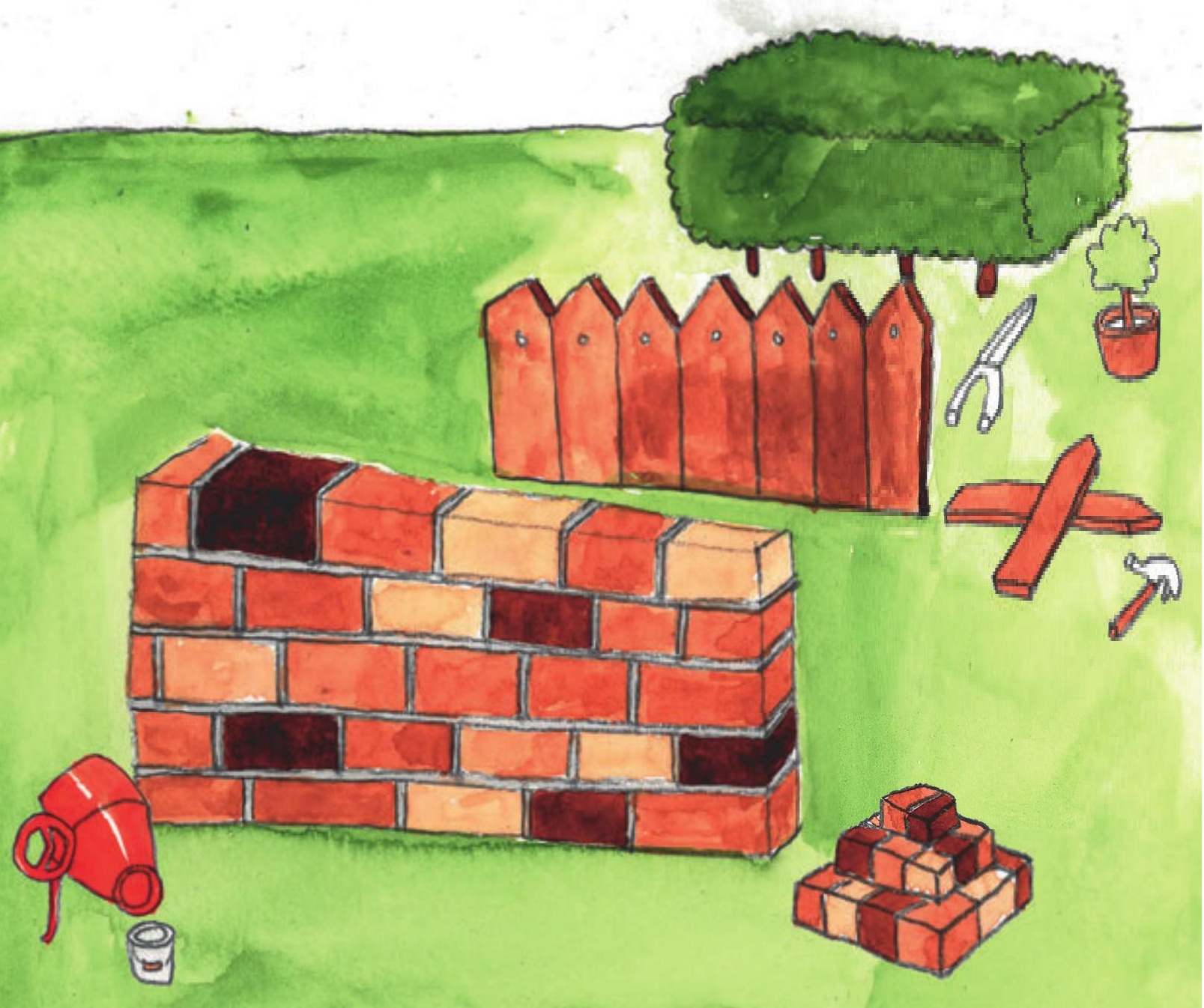




\section{Chapter 6}

\section{Student participation in the design of learning and teaching: Disentangling the terminology and approaches}

Martens, S. E., Meeuwissen, S. N. E., Dolmans, D. H. J. M., Bovill, C., \& Könings, K. D. (2019). Student participation in the design of learning and teaching: Disentangling the terminology and approaches. Medical Teacher, 41(10), 1203- 


\section{Abstract}

Background: Students are ever more involved in the design of educational practices, which is reflected in the growing body of literature about approaches to student participation. Similarities and differences between these approaches often remain vague since the terms are used interchangeably. This confusing and fragmented body of literature hampers our understanding the process and outcomes of student participation and choosing the most suitable approach for it.

Method: We identified the three most frequently used terms related to the design of learning and teaching - design-based research (DBR), participatory design (PD), and co-creation - and disentangled the terminology by focusing on relevant definitions, aims, involvement of students, outcomes, and related terminology.

Results: Differences between the approaches to student participation can be found in the degree to which students are the central actors and the degree to which the design is informed by educational theory.

Conclusion: It is important to align the level of student participation with the purpose of the approach. 


\section{Introduction}

Students are ever more involved in the design of educational practices (e.g. Bovill et al. 2016), which is reflected in the growing body of educational literature about approaches to student participation: design-based research (DBR), participatory design (PD), co-creation, co-design, student voice, student-staff partnership, students as change agents, student engagement, and student empowerment (Seale 2009; Anderson and Shattuck 2012; Bovill et al. 2016). Peters et al. (2018) recently stressed the different understandings of student engagement in medical education. Yet despite these different understandings, the ASPIRE to Excellence award initiative was launched by the International Association for Medical Education in Europe (AMEE) for recognition of international excellence in medical, dental and veterinary schools for student engagement in the curriculum (ASPIRE initiative 2012). Similarities and differences between the different approaches of involving students in the design of educational practices have remained vague and terminology is confusing. Several conceptual models on student participation in the educational design process are used. Druin (2002) described different students' roles in the design process, and Bovill and Bulley (2011) developed a "Ladder of student participation in curriculum design" (p. 5), showing eight rungs on a continuum of student participation. Although these models are helpful in practice, they do not take away the entanglement of terminology of approaches used in the field. The fragmentation of the literature hampers our understanding of the processes and outcomes of student participation as well as choosing the most suitable approach for it. We recognize the overlapping nature of many definitions, but we aimed to disentangle the terminology of different approaches to student participation in educational design and to situate this terminology in existing models on student participation.

\section{Methods}

We explored the frequency of use of different terms related to student participation in the design of learning and teaching by determining the amount of hits from any year and within the general field of education in Web of Science. Search terms were: DBR, PD, co-creation, co-design, student voice, student-staff partnership, student-faculty partnership, students as partners, students as change agents, student engagement, student empowerment, student participation, student-staff collaboration, and student-faculty collaboration, in combination with the search 
term education. All types of articles were included. The purpose of this search was to provide a rough estimate of the prevalence of each term in the general educational literature.

We identified the most frequently used terms that related to student participation in educational design: DBR, PD, student voice, and co-creation. While reading the articles, we noticed that the term student voice is often used differently in a more passive and active way, in the context of what we consider respectively PD and co-creation. Therefore we decided not to use student voice as a term by itself, but to highlight where student voice relates to both PD and co-creation. We then searched for relevant definitions, aims, involvement of stakeholders, outcomes and benefits, and related terminology for each of the terms. Based upon key literature on DBR, PD, and co-creation, most commonly related terms for each concept were included.

\section{Results}

\section{Design-Based Research}

DBR is a collaboration of researchers and educational practitioners whereby they develop answers to educational problems and advance theoretical understanding. The design of the learning environment is informed by educational theories. The aim of DBR is to improve both the design of the learning environment and to develop and refine educational theories (Anderson and Shattuck 2012; Dolmans and Tigelaar 2012). Apart from researchers and educational practitioners, other stakeholders can be involved in an iterative design process such as students and educational designers. Students' role is often limited to provide input; they are not put forward as central actors within the design process (McKenney and Reeves 2012). Benefits of DBR are improving educational practice and theory by testing and refining educational design guidelines about what might work under which conditions and why. Terms that are often used in relation to DBR are development research and design experiments (e.g. Anderson and Shattuck 2012).

\section{Participatory Design}

PD is a collaboration of all stakeholders, including students, whereby they design and develop innovations that are tailored to the learners and context (Cober et al. 2015; Könings and McKenney 2017; Könings et al. 2017). The goal 
of PD is to improve quality of educational innovations by ensuring use, usability and utility of educational design for both teachers and students (DiSalvo et al. 2017). Starting from the idea that all stakeholders' knowledge and expertise is highly valued, teachers, educational designers, and students collaborate (Seale, 2009). Benefits of PD exists for teachers and students in their own local practice: The implementation of new tailor-made educational designs (Cober et al. 2015). Terms that are intertwined are co-design, collaborative design, student voice and student participation (when only listening to students), and student engagement (e.g. Cober et al. 2015).

\section{Co-creation}

Co-creation is a close collaboration of students and teachers. The aim is to intensify active engagement of students in the educational (design) process and to improve teaching and learning by welcoming students' perspectives (Bovill et al. 2016). This goes beyond only listening to student voices. The focus within cocreation is on empowering students to actively collaborate with teachers (Bovill et al. 2011). Within co-creation, students' roles range from being involved with limited influence on decision-making to working in a partnership with teachers (Delpish et al. 2010). Partnership is characterized by a focus on equality between students and staff (Cook-Sather et al. 2014). Benefits for staff, students, and institutions include enhanced satisfaction and engagement, motivation and learning, meta-cognitive skills, improved quality of student-teacher interactions, and development of graduate competencies such as leadership skills (CookSather et al. 2014). Related terms are student-staff partnership, student voice (when actively involved), active student participation, students as partners/change agents, and student empowerment (e.g. Seale 2009).

\section{Application to Models}

Linking the different approaches to the existing models on student participation makes clear they include all three approaches (see Figure 1). The model of Druin (2002) describes four roles: Students as users, testers, informants and design partners. In DBR students are generally users and to some extent testers, being included in the analysis and evaluation phase and less in the design phase, whereas in PD, students are more usually testers and informants who participate in the 
design and development of tailor-made innovations. In co-creation, involvement of students can go up to being equal stakeholders in the design process. Applying the approaches to the "ladder of student participation" of Bovill and Bulley (2011), DBR can be placed on the ladder of participation at the two bottom rungs, where students evaluate rather than having control of their curriculum. PD is situated at the following two rungs, providing students with some choice. Finally, co-creation refers to the upper end of the ladder, as student participation is on its highest level with students having more influence on decision-making.
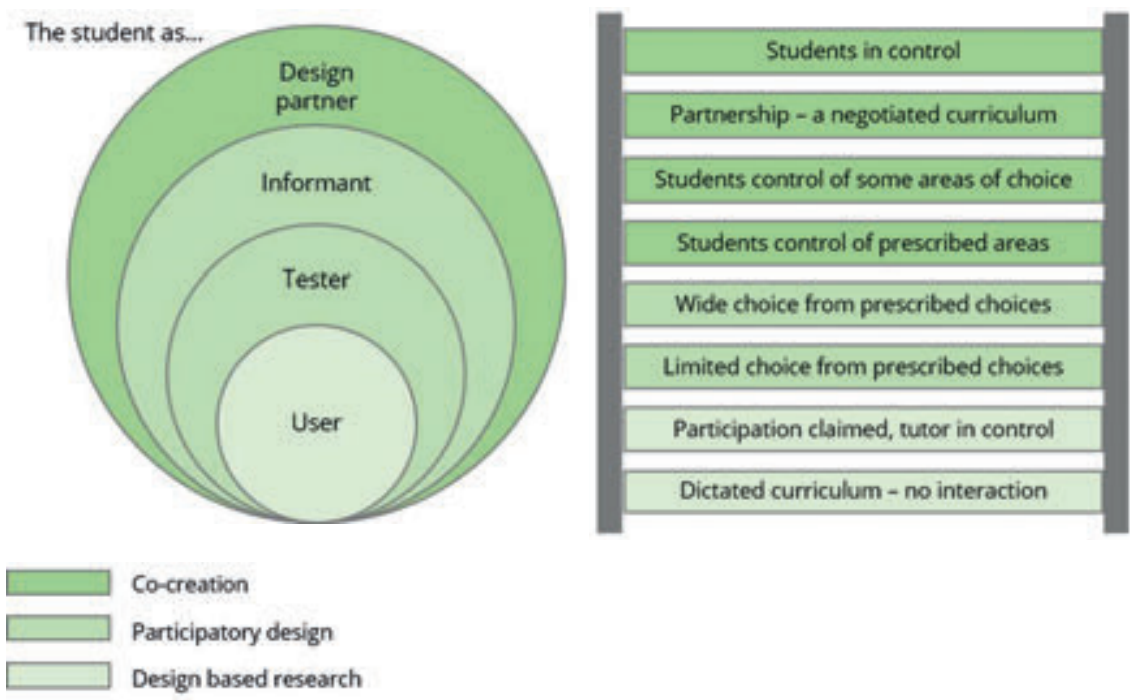

Figure 1. Indication of the links between the three approaches DBR, PD and co-creation, and existing models on different roles of students in education design. Adapted from the onion-model by Druin (2002) and the ladder of student participation by Bovill and Bulley (2011).

\section{Discussion and Conclusions}

There is clearly much overlap between these terms. The similarity between DBR, PD and co-creation is in valuing the input of students as stakeholders in the educational design process. However, in trying to differentiate terms, key differences lie in the level of student participation in the design process and the focus on educational theory. Students being the central actors increase from DBR to co-creation, while the focus on educational theory decreases. It is therefore important that the level of student participation is aligned with the purpose of the approach. 


\section{Implications}

Attempting to disentangle terminology helps in preventing interchangeable usage of terms and contributes to deeper understanding of the processes and outcomes of student participation in the design of learning and teaching. With the demarcation of approaches, we invite researchers and practitioners to clearly define their approach while studying processes and outcomes of student participation. If answers to educational problems have to be developed and the aim is to advance theoretical understanding beyond local relevance only, DBR may be the best approach and students are mainly involved in evaluation. In contrast, in PD, stakeholders including students design and develop local innovations that are tailor-made educational designs. Co-creation is a more suitable approach if the aim is to improve active student engagement, student experience and effectiveness of the learning environment. Practically, disentangling the approaches enables teachers and medical schools to make more conscious decisions on which approach for student participation to choose, aligned with the aims pursued in the design process of learning and teaching. 


\section{References}

Anderson T, Shattuck J. 2012. Design-based research: a decade of progress in education research? Educ Res. 41:16-25.

ASPIRE initiative: International Association for Medical Education in Europe. 2012. [accessed 2019 Apr 15]. https://www.aspire-to-excellence.org/.

Bovill C, Bulley C. 2011. A model of active student participation in curriculum design-exploring desirability and possibility. In: Rust C, editor. Improving Student Learning (18) Global theories and local practices: Institutional, disciplinary and cultural variations. Oxford: The Oxford centre for staff and educational development; p. 176-188.

Bovill C, Cook-Sather A, Felten P. 2011. Students as co-creators of teaching approaches, course design, and curricula: implications for academic developers. Int J Acad Dev. 16:133-145.

Bovill C, Cook-Sather A, Felten, P, Millard L, \& Moore-Cherry, N. 2016. Addressing potential challenges in co-creating learning and teaching: overcoming resistance, navigating institutional norms and ensuring inclusivity in student-staff partnerships. High Educ. 71:195-208.

Cober R, Tan E, Slotta J, So HJ, \& Könings KD. 2015. Teachers as participatory designers: two case studies with technology-enhanced learning environments. Instr Sci. 43:203-228.

Cook-Sather A, Bovill C, \& Felten P. 2014. Engaging students as partners in learning and teaching: a guide for faculty. San Francisco (CA): Jossey-Bass.

Delpish A, Darby A, Holmes A, Knight-McKenna M, Mihans R, King C, \& Felten P. 2010. Equalizing voices: student-faculty partnership in course design. In: Werder C, Otis M, editors. Engaging student voices: in the study of teaching and learning. Sterling (VA): Stylus Publishing; p. 96-114.

Di Salvo B, Yip J, Bonsignore E, \& Di Salvo C. 2017. Participatory design for learning. New York (NY): Routledge.

Dolmans HJM, Tigelaar D. 2012. Building bridges between theory and practice in medical education using a design-based research approach: AMEE Guide No. 60.

Druin A. 2002. The role of children in the design of new technology. Behav Inform Technol. 21:1-24.

Könings KD, Bovill C, Woolner P. 2017. Towards an interdisciplinary model of practice for participatory building design in education. Eur J Educ. 52:306-3017. Könings KD, McKenney S. 2017. Participatory design of (built) learning environments. Eur J Educ. 52:247-252.

McKenney S, Reeves TC. 2012. Conducting educational design research. Abingdon: Routledge.

Peters H, Zdravkovic M, Costa MJ, Celenza A, Ghias K, Klamen D, Mossop L, Rieder M, Nadarajah VD, Wangsaturaka D, et al. 2018. Twelve tips for enhancing student engagement. Med Teach.

Seale J. 2009. Doing student voice work in higher education: an exploration of the value of participatory methods. Br Educ Res J. 36:995-1015. 


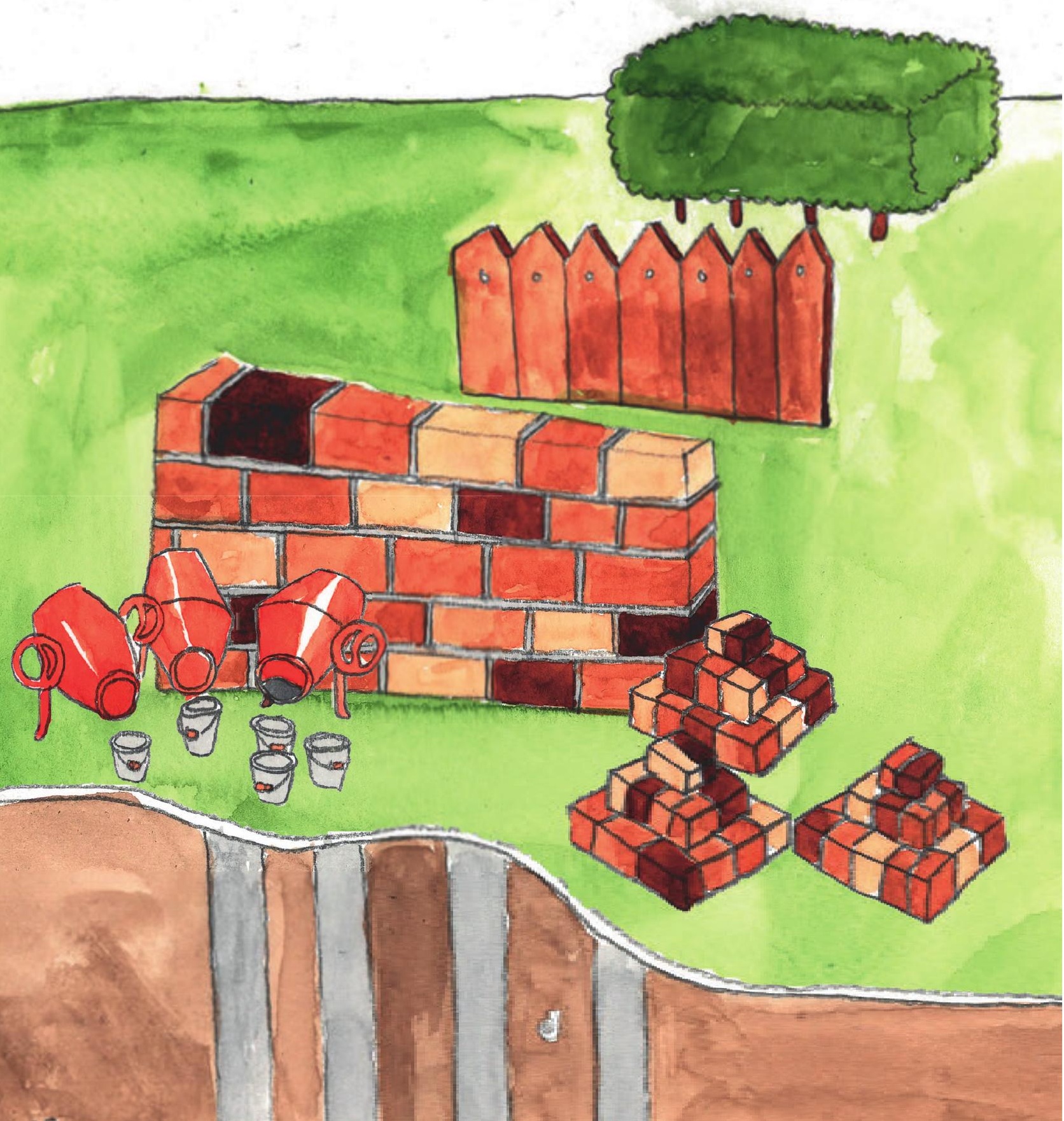


Chapter 7

General discussion 


\section{Introduction}

The idea of students and staff members working together to improve education is gaining momentum in higher education (Barradell \& Bell, 2020). One way to shape such practice is to establish student-staff partnerships (SSPs) (Isaeva, Eisenschmidt, Vanari, \& Kumpas-Lenk, 2020). Throughout this dissertation, we used Cook-Sather, Bovill, and Felten's (2014) definition of SSP as 'a collaborative, reciprocal process through which all participants have the opportunity to contribute equally, although not necessarily in the same ways, to curricular or pedagogical conceptualization, decision making, implementation, investigation or analysis' (p. 6-7). By combining both students and staff members' unique perspectives in efforts to improve the quality of education, SSPs have the potential to enhance learning and teaching practices (Isaeva et al., 2020; Könings et al., 2014; Matthews et al., 2018). We discerned three different levels of student participation, of which SSP can be considered the highest one. Before this level, we find the 'student as adviser', referring to students giving feedback through evaluation questionnaires or by taking part in advisory committees that staff members can act upon. The first and lowest level of student participation is 'no student involvement', which is the case when students do not participate at all or merely share their suggestions, without staff members acting upon them (Bovill \& Bulley, 2011; Fielding, 2011; HEA NUS, 2011). SSPs have received greater attention in the last decade. Previous research has shown that students sometimes feel they are not taken seriously in endeavours to enhance the quality of education and that staff members can be hesitant to involve students in these ventures (Bicket, Misra, Wright, \& Shochet, 2010; Bovill, Cook-Sather, Felten, Millard, \& Moore-Cherry, 2016). SSPs might help to eliminate staff members' doubts and ensure that students are taken seriously.

Based on previous research, we assumed that reciprocal respect, responsibility/ownership, empowerment and commitment are crucial to the success of SSPs (Abbot \& Cook-Sather, 2020; Chapman, Blatchford, \& Hughes, 2013; CookSather et al., 2014; Healey et al., 2014). The first of these prerequisites, reciprocal respect, means that students and staff members must appreciate each other, take each other seriously and exchange thoughts in an equal manner (Cook-Sather et al., 2014). The responsibility/ownership prerequisite, on the other hand, requires that all participants feel responsible for improving the educational system (Bendermacher et al., 2016; Pierce et al., 2003). Third, 'empowerment' implies that all partners in SSPS must be confident that they can actually contribute to 
educational improvement and at the same time have the autonomy to decide for themselves how they do their job (Menon, 1999; Spreitzer, 1995). Finally, 'commitment' denotes that students and staff members must be willing to put extra effort into improving education and be worried about its quality (Bendermacher et al., 2016). Although several examples of SSPs have been described, little empirical evidence exists as yet on how to attain SSPS, especially in course and curriculum design (Healey \& Healey, 2019). While the emphasis in the current literature is on case studies of the benefits that SSPs bring, the challenges and approaches to solve these have received scant attention (Barradell \& Bell, 2020; MercerMapstone et al., 2017). How students and staff members perceive these SSPs has remained underexplored, offering room for a further exploration of students and staff members' positive experiences, the challenges they experience and their preferences. Questions that need addressing at this point are: Are all students willing to participate in SSPS or is such involvement only the preserve of students who are already actively involved? Similarly, how do the above prerequisites relate to each other and which of these predict SSPs? And what about staff members' perspectives? The aim of the present dissertation was to explore SSPS, that is, to understand how different stakeholders - students who are actively involved, the broader student population and staff members - can encourage SSPs in order to improve educational quality. With this in mind, the dissertation examined the following research questions:

1. What are students' current experiences and preferences regarding SSPS, and the prerequisites to making a useful contribution to SSPs? (Chapters 2, 3, and 4)

2. What are staff members' conceptions of SSPs and the prerequisites that render SSPs effective? (Chapter 5)

\section{Discussion of the main findings}

\section{What are students' current experiences and preferences regarding} SSPs, and the prerequisites to making a useful contribution to SSPs?

To answer our first research question, we focused on two aspects: (1) Students' experiences and preferences regarding SSPs, and (2) the prerequisites for attaining SSPS, according to students. In chapter 2, we started our venture by zooming in on students who were already actively involved in the process of evaluating or 
improving education, for instance in evaluation panels or course design or redesign teams. This study demonstrated that students who were already actively involved in such processes were willing to participate in SSPS. More specifically, students argued that, while they appreciated staff members' content and didactic knowledge, they felt they could make a meaningful contribution by putting forward new ideas and suggestions and performing a practicality check: Checking whether something would be feasible for them. In this way, they felt they could provide a unique perspective on how to improve the quality of education. The positive results of chapter 2 made us wonder if the same results would apply to the broader student population as well and, if so, what their preferred level of participation would be: The level of advisers (by participating in advisory bodies) or of partners (by participating in teams in which they would design or redesign, implement and evaluate education in collaboration with staff members as their true partners)? We concluded in chapter 3 that the broader student population indeed preferred to be more actively involved. Not only did they indicate a wish to develop a stronger profile as an adviser, they were also willing to become a partner in enhancing educational quality, for instance by contributing to the design or redesign of courses. Overall, we learnt that students wished to participate more actively in enhancing educational quality. Concurrently, we also concluded that students did not yet fully experience the level of student participation they preferred.

Chapters 2 and 3 also shed light on the second part of the first research question: The prerequisites for making a useful contribution to SSPs. The findings from these chapters demonstrated that students preferred to be involved not only in the evaluation phase, but also in the implementation phase of improving education. Although they felt respected by staff, they also expressed a wish to be informed of whether their suggestions had been taken up, and to be seen as equal partners without discounting the difference in students and staff members' roles. We further concluded that communication or dialogues between students and staff members should be improved and that the perspectives of the broader student population should be included to improve the quality of courses and curricula. Moreover, organisational support for students and staff members also seemed to be an important factor in the success of SSPS, a conclusion we saw confirmed by the study reported in chapter 4 . In this chapter we conducted a path analysis to examine the relationships between the perceived prerequisites for SSPs and students' preferences for SSP. Our findings supported the hypothesis that 
a supportive organisation would be an important prerequisite necessary to creating a culture of reciprocal respect, effective communication and commitment, and that commitment, in turn, would predict students' preferences for SSPs. By 'supportive', we mean an organisation that offers sufficient resources to facilitate student participation, not only by educating students about improving education for example, but also by encouraging a culture of collaboration and teamwork and having a clear vision for how to actively engage students in such improvement efforts.

The present dissertation is consistent with findings from previous research demonstrating that students do not always feel sufficiently valued, appreciated and respected (Bicket et al., 2010). We have learnt that students experience some reciprocal respect, but not as much as they would like. Although most staff members were open to feedback and conversations, there were still several instances in which students were confronted with staff members who were hesitant and not very receptive to their feedback or to their involvement in the design or redesign of courses. Some students felt their contribution was not really appreciated by some staff members or taken seriously. These findings tie in with those of Barradell and Bell (2020) who argued that students sometimes experienced apathy amongst staff members. Moreover, our studies demonstrated that students would like to be more involved in enhancing educational quality. This observation finds resonance in a study by Isaeva et al. (2020) who concludes that students are eager to be involved in dialogues to improve education. While commitment is an important prerequisite (Healey, Lerczak, Welsh, \& France, 2019; Higgins, Dennis, Stoddard, Maier, \& Howitt, 2019), the studies in this dissertation demonstrated that communication is also an important prerequisite of SSPS based on students' and staff members' perspectives, which is also in line with the studies of Abbot and Cook-Sather (2020) and Gravett, Kinchin, and Winstone (2019). Finally, we learnt that empowerment should be considered an essential component of SSPs, rather than a prerequisite. Consequently, students and staff members should adapt to new power balances in SSPs, so that students become empowered when taking part in SSPs. As Higgins et al. (2019) were already keen to point out, SSPs imply empowerment; empowerment belongs to the core of SSP. 


\section{What are staff members' conceptions of SSPs and the prerequisites that render SSPs effective?}

So far, we have gained more insight into the perspectives of students. Our next step was to explore the perspectives of staff members. In doing so, we focused on two aspects: (1) Staff members' conceptions of student participation and of SSPs in particular, and (2) the prerequisites for effective SSPS. In chapter 5 we concluded that staff members had differing conceptions of student participation, ranging from the view that limited space should be allocated to students in course redesign, through an appreciation of student feedback on how to improve courses, to the belief that students and staff members can participate in the creation and redesign of courses. We also learnt that staff members did not always realise they could invite students to be involved in the design or redesign of courses as partners. With respect to the prerequisites for rendering SSPs effective, chapter 5 found that staff members considered co-creation with students in SSPs as attainable, provided several conditions were met. These were: Staff members should be open to student involvement and they should have the final say; students should be motivated and able to communicate; students and staff members should have dialogues to explore each other's perspectives; and the organisation should be supportive.

Although staff members were willing to move towards SSPs, they emphasised that they wanted to maintain the final say, indicating that these staff members might not have crossed the SSP threshold yet. In this sense, threshold refers to "'conceptual gateways" or "portals" that lead to a previously inaccessible, and initially perhaps "troublesome", way of thinking about something' (Meyer \& Land, 2005, p. 373). Crossing a threshold changes one's view on the subject matter (Meyer \& Land, 2005). In other words, once students and staff members have experienced a successful SSP, they might change their perception of how to involve students in improving education. Experiencing an SSP could change students and staff members' views on student participation. At this point it can still feel threatening to staff members to share power, but once they have successfully experienced SSPS, they will embrace it (Cook-Sather, 2014). As such, SSPs require a new, collaboration-oriented mindset (Matthews, 2016). A next step is to offer staff members the opportunity to participate in SSPs in course or curriculum improvement. 


\section{Taking stock - looking forward}

The studies by Mercer-Mapstone et al. (2017) and Könings, Mordang, Smeenk, Stassen, and Ramani (2020) underscored the importance of recognising the reality and the challenges of SSPS. SSP implementation requires quite a shift from the traditional staff and student roles that are characterised by a power imbalance: While staff members take care of the design of education, students receive or consume education. Consequently, putting SSPs into practice might be easier said than done. Although students and staff members are open to SSPs, new challenges lie ahead. First, as SSPs span a wide range of activities, Barradell and Bell (2020) have warned for pseudo-SSPs: Student participation initiatives that are not consistent with Cook-Sather et al.'s (2014) definition of SSP and therefore cannot be called true partnerships. At the same time, Healey, Flint, and Harrington (2014) have argued that there is more to SSPs than mere outcomes or visible results, such as the process of learning and working together. This begs the question: If staff members and students do not share the final responsibility in course design, can they truly contribute in an equal manner? This question will need further exploration in future studies. Second, although the broader student population has indicated a preference for SSP, we could question the feasibility of involving this entire population as partners beyond the students who already have experience in advisory roles. On the one hand, it might not be easy to recruit these students and to involve them as partners, because not all of them would qualify, according to staff members, since not all would be able to offer quality contributions, communicate well about the educational challenges they face and give good suggestions on what to improve. Moreover, their perceptions are likely to reflect an advisory role rather than a true partner role. On the other hand, however, it might be meaningful to include students from this group as partners as they would better represent the broader student population. Hence, this is another issue that needs further exploration. Finally, it is important to keep in mind that the growing body of literature on approaches to student participation often uses different terms, such as co-creation, co-design, student voice, student-staff partnership, students as change agents, student engagement and student empowerment (Anderson \& Shattuck, 2012; Bovill et al., 2016; Seale, 2009). In chapter 6 we disentangled the relevant terminology and approaches and discovered that there is clearly much overlap between these terms and approaches. What they all share in common is that they value the input 
of students as stakeholders in the educational design process. However, in trying to differentiate terms, key differences lie in the level of student participation in the design process. Co-creation seems to be a suitable approach if the aim is to improve active student engagement, students' experience and the effectiveness of the learning environment.

\section{Strengths and weaknesses}

This dissertation has several strengths. The first is that we involved a variegated range of stakeholders in our studies, including staff members as well as students and combining both of their perspectives on SSPs. Moreover, not only did we invite students who were already actively involved in, for instance, evaluation panels or course design or redesign teams, but we also selected students who would otherwise not have been involved in educational improvement efforts. By combining these perspectives, we were able to give a broader picture of the current support base for SSPs. The second strength is that we applied multiple methods to examine SSPs, using both quantitative and qualitative approaches, including surveys, interviews and focus groups.

Despite these strengths, the present dissertation also has some limitations. First, the studies were conducted at the Faculty of Health, Medicine and Life Sciences of Maastricht University which is known for its Problem-Based Learning (PBL) approach. In a PBL context, students regularly meet with staff members in small groups to discuss and learn from each other and hence they already have a close connection. These circumstances might have caused students and staff members to be biased towards SSP. Second, although we conducted surveys, focus groups and interviews to identify students and staff members' experiences and preferences, we did not implement and evaluate specific activities to enhance SSP in our educational practice beyond our regular practices of letting all students evaluate their teaching and letting some of them participate in advisory bodies or course design teams. Third, this dissertation lacked information on another important stakeholder: The management team. Since this dissertation suggested that a supportive organisation might facilitate SSPs, it would have been interesting to learn more about their take on SSPs. 


\section{Future research}

Further research in the field of SSPs would help to support their implementation. We welcome future studies that aim to design specific SSP activities in which students and staff members design and redesign, implement and evaluate courses together. An example would be to let students design course materials, such as cases to be discussed by students in a course, in collaboration with staff members. These activities could subsequently be implemented and evaluated using the surveys and interviews developed in the studies of this dissertation. We also recommend training for both students and staff members in how to put SSPs into practice. Likewise, we invite scholars to observe the collaboration between students and staff members during such SSP activities and to evaluate their effectiveness afterwards. Lastly, a logical sequel to this work would be to analyse the perspectives of managers: How do managers think their organisation can support SSPs?

\section{Practical implications}

Organising SSPs is no easy feat. While underscoring the fact that establishing SSPs requires effort, the present dissertation draws attention to the following implications: (1) Raise awareness amongst students and staff members, and (2) put SSPs into practice. First, we need to raise awareness amongst students and staff members by informing them about the meaning, importance, benefits and challenges of SSPS. The start of the academic year would be a good occasion to do so. Second, it would be meaningful to organise co-creation sessions in which students and staff members design or redesign courses together. To become aware of their responsibilities, students and staff should clearly define and communicate their roles. Training and coaching sessions should be organised focused on helping students and staff members understand each other's perspectives during SSP implementation. We highly recommend regular dialogues and evaluation sessions during and after the design or redesign, implementation and evaluation of courses. 


\section{Conclusion}

We have learnt that students wished to be more actively involved as partners in efforts to improve education. Yet, they did not yet fully experience the level of student participation they preferred. This held true for both students who were already actively involved in efforts to improve education and those who were not. Staff members valued students for their role of providing feedback and were willing to involve students in efforts to co-create teaching and learning. However, they also pointed out that students should be motivated and able to communicate and that staff members should have the final say. Overall, students and staff members were willing to participate in SSPs for the purpose of improving the quality of education together. While both partners did not yet experience fully fledged SSPS, they embraced the idea of moving in that direction. Although they both acknowledged students' unique perspective, participating in SSPs was seen as a challenging task for students since staff members were not always very receptive to their suggestions. Similarly, it was challenging for staff members, and students too, to share power. Finally, to render SSPs successful, certain conditions, such as commitment, reciprocal respect, good communication and a supportive organisation should be met. 


\section{References}

Abbot, S., \& Cook-Sather, A. (2020). The productive potential of pedagogical disagreements in classroom-focused student-staff partnerships. Higher Education Research and Development, 39(7), 1396-1409. https://doi.org/10.1080/07294360.2020.1735315

Anderson, T., \& Shattuck, J. (2012). Design-Based Research: A Decade of Progress in Education Research? Educational Researcher, 41(1), 16-25. https://doi. org/10.3102/0013189X11428813

Barradell, S., \& Bell, A. (2020). Is health professional education making the most of the idea of 'students as partners'? Insights from a qualitative research synthesis. In Advances in Health Sciences Education. https://doi.org/10.1007/s10459-020-09998-3

Bendermacher, G. W. G., Oude Egbrink, M. G. A., Wolfhagen, I. H. A. P., \& Dolmans, D. H. J. M. (2016). Unravelling quality culture in higher education: A realist review. Higher Education, 1-22. https://doi.org/10.1007/s10734-015-9979-2

Bicket, M., Misra, S., Wright, S. M., \& Shochet, R. (2010). Medical student engagement and leadership within a new learning community. BMC Medical Education, 10, 20. https:// doi.org/http://dx.doi.org/10.1186/1472-6920-10-20

Bovill, C, \& Bulley, C. (2011). A model of active student participation in curriculum designexploring desirability and possibility. In C. Rust (Ed.), Improving Student Learning (18) Global theories and local practices: Institutional, disciplinary and cultural variations. (pp. 176-188). Oxford: the Oxford centre for staff and educational development.

Bovill, C, Cook-Sather, A., Felten, P., Millard, L., \& Moore-Cherry, N. (2016). Addressing potential challenges in co-creating learning and teaching: Overcoming resistance, navigating institutional norms and ensuring inclusivity in student-staff partnerships. Higher Education, 71(2), 195-208. https://doi.org/10.1007/s10734-015-9896-4

Chapman, P., Blatchford, S., \& Hughes, E. (2013). Lightening up the dark side: A partnership approach between a students' union and the university. In C. Nygaard, S. Brand, P. Bartholomew, \& L. Millard (Eds.), Student engagement: Identity, motivation and community (pp. 271-290). Oxfordshire: Libri Publishing.

Cook-Sather, A. (2014). Student-faculty partnership in explorations of pedagogical practice: a threshold concept in academic development. International Journal for Academic Development, 19(3), 186-198. https://doi.org/10.1080/1360144X.2013.805694

Cook-Sather, A., Bovill, C., \& Felten, P. (2014). Engaging students as partners in learning and teaching: A guide for faculty (First; A. Cook-Sather, C. Bovill, \& P. Felten, eds.). San Francisco: Jossey-Bass.

Fielding, M. (2011). Patterns of partnership: Student voice, intergenerational learning and democratic fellowship rethinking educational practice through reflexive research : Essays in honour of Susan Groundwater-Smith Nicole Mockler and Judyth Sachs (eds) (2011).

Gravett, K., Kinchin, I. M., \& Winstone, N. E. (2019). 'More than customers': conceptions of students as partners held by students, staff, and institutional leaders. Studies in Higher Education, 45(12), 2574-2587. https://doi.org/10.1080/03075079.2019.1623769

HEA NUS. (2011). Student engagement toolkit. Higher Education Academy and National Union of Students. Available from: www.nusconnect.org.uk/campaigns/highereducation/ student-engagement/toolkit/resources/ 
Healey, M., Flint, A., \& Harrington, K. (2014). Engagement through partnership : students as partners in learning and teaching in higher education. THe Higher Education Academy Report, (July), 1-76. https://doi.org/10.1080/1360144X.2016.1124966

Healey, M., \& Healey, R. L. (2019). Students as partners guide: Student engagement through partnership a guide to the advance he framework student engagement through partnership.

Healey, R. L., Lerczak, A., Welsh, K., \& France, D. (2019). By any other name? The impacts of differing assumptions, expectations, and misconceptions in bringing about resistance to student-staff partnership. International Journal for Students as Partners, 3(1), 106122. https://doi.org/10.15173/ijsap.v3i1.3550

Higgins, D., Dennis, A., Stoddard, A., Maier, A. G., \& Howitt, S. (2019). 'Power to empower': conceptions of teaching and learning in a pedagogical co-design partnership. Higher Education Research \& Development, 38(6), 1154-1167. https://doi.org/10.1080/0729436 0.2019 .1621270

Isaeva, R., Eisenschmidt, E., Vanari, K., \& Kumpas-Lenk, K. (2020). Students' views on dialogue: Improving student engagement in the quality assurance process. Quality in Higher Education, 26(1), 80-97. https://doi.org/10.1080/13538322.2020.1729307

Könings, K. D., Mordang, S., Smeenk, F., Stassen, L., \& Ramani, S. (2020). Learner involvement in the co-creation of teaching and learning: AMEE Guide No. 138. Medical Teacher, $0(0)$, 1-13. https://doi.org/10.1080/0142159X.2020.1838464

Könings, K. D., Seidel, T., \& van Merriënboer, J. J. G. (2014). Participatory design of learning environments: Integrating perspectives of students, teachers, and designers. Instructional Science, 42(1), 1-9. https://doi.org/10.1007/s11251-013-9305-2

Matthews, K. E. (2016). Students as partners as the future of student engagement. Student Engagement in Higher Education Journal, 1(1), 1-5.

Matthews, K. E., Dwyer, A., Hine, L., \& Turner, J. (2018). Conceptions of students as partners. Higher Education, 76(6), 957-971. https://doi.org/10.1007/s10734-018-0257-y

Menon, S. T. (1999). Psychological empowerment: Definition, measurement, and validation. Canadian Journal of Behavioural Science, 31(3), 161-164. https://doi.org/http://dx.doi. org/10.1037/h0087084

Mercer-Mapstone, L., Dvorakova, S. L., Matthews, K. E., Abbot, S., Cheng, B., Felten, P., ... Swaim, K. (2017). A Systematic Literature Review of Students as Partners in Higher Education. International Journal for Students as Partners, 1(1), 1-23.

Meyer, J. H. F., \& Land, R. (2005). Threshold concepts and troublesome knowledge (2): Epistemological considerations and a conceptual framework for teaching and learning. Higher Education, 49(3), 373-388. https://doi.org/10.1007/s10734-004-6779-5

Pierce, J. L., Kostova, T., \& Dirks, K. T. (2003). The state of psychological ownership: integrating and extending a century of research abstract. Review of General Psychology, 7(314), 1-35. https://doi.org/10.1037/1089-2680.7.1.84

Seale, J. (2009). Doing student voice work in higher education: an exploration of the value of participatory methods. British Educational Research Journal, 36(6), 995-1015. https:// doi.org/10.1080/01411920903342038

Spreitzer, G. M. (1995). Psychological Empowerment in the Workplace: Dimensions, Measurement, and Validation. The Academy of Management Journal, 38(5), 1442-1465. 


\section{Addendum}

Summary

Samenvatting

Impact chapter

Dankwoord

About the author

SHE dissertation series

ICO dissertation series 


\section{Summary}

The aim of the current dissertation is to contribute building student-staff partnerships (SSPS). SSPs can be defined as: 'a collaborative, reciprocal process through which all participants have the opportunity to contribute equally, although not necessarily in the same ways, to curricular or pedagogical conceptualization, decision making, implementation, investigation or analysis' (Cook-Sather, Bovill, \& Felten, 2014, p. 6-7). They can be a helpful approach to enhance learning and teaching practices, since both students and staff member bring their unique perspectives and experiences to an encounter. Chapter 1 provides a general introduction to the topic. Not yet much is known about how students experience their current involvement in enhancing educational quality and what their preferences are. Despite the fact that reports are written on examples of SSPs, little empirical evidence exists. Are all students willing to participate in SSPs or might this only be of interest to students who are already actively involved? Or is it sufficient when students provide feedback in an adviser role? At the same time, we describe we assume that respect, reciprocity, responsibility/ownership, empowerment, and commitment are variables which are crucial for a successful SSP. But, we wonder which prerequisites are most important to students. And what about staff members' perspective? They might face barriers to implement SSPs as well. Both students and staff members' perspectives of these SSPs have hitherto not been fully explored. Therefore, the main aim of this dissertation is to explore students' and staff members' perspectives reflected in two main research questions:

1. What are students' current experiences and preferences regarding SSPS, and the prerequisites to making a useful contribution to SSPs? (Chapters 2, 3, and 4)

2. What are staff members' conceptions of SSPS and the prerequisites that render SSPs effective? (Chapter 5)

Chapter 2 describes a mixed-method study intended to examine how students currently perceive their student-staff collaboration. More specifically, the aim was to investigate whether students are willing to participate in SSPs, how students' experiences differ from their preferred situation, and why and under which circumstances students perceive their contribution to SSP as effective. 
This study was conducted among a specific group of students, that is students who were already actively involved in for instance evaluation panels, course (re) design teams, or in the management team. Questionnaires and focus groups were conducted to gather more insights in perceptions of students. The results indicate that currently students do not experience full SSPs yet. Crucial aspect is that they perceive to have limited influence in shared decision-making and implementation processes. Students feel they are not yet involved in the implementation process: Their influence is limited to giving advice. Taking students' preferences into account, findings indicate that students are willing to be more involved in educational improvement and they prefer to be seen as equal partners, although their input does not have to be the same as staff members' input: Given differences in expertise. When asked what is needed to get to that situation, students mention the importance of clearly defining who could fulfil which roles and what their responsibilities are. Roles should be formalised, but its informality should not be lost. This study provides deeper insights into how a SSP is experienced by students who are already actively involved, what they prefer, and under what circumstances a partnership could be effective. It becomes clear that in order to facilitate effective student-staff partnerships, some specific prerequisites should be met.

Chapter 3 describes a questionnaire study, in which the focus was on exploring the broader student populations' perspective regarding experiences in and preferences to the role of adviser - enabling staff members to improve education, and to the role of partner in an SSP. That is, it is one thing for a select group of students who are already much involved in educational processes, but what about a whole cohort of students. Would they be interested in SSP? The aim of the study was to identify how to bridge the (potential) gap between students' current experiences and their preferences. A questionnaire measuring both roles for the current and preferred situation, and open-ended questions was conducted. The results demonstrate that students would prefer to participate more actively than they currently do. On the one hand, they would like to develop a stronger profile as an adviser by providing active feedback on enhancing educational quality. On the other hand, students are willing to take student participation a step further and become a partner for instance by (re)designing courses. Students offer suggestion on how to get to an SSP: They want transparent disclosure of what happens to their improvement suggestions, they would like to improve the dialogue between students and staff members who are involved in educational 
development, and they would like to have open, informal meetings to include the perspective of the broader student population. This chapter identified the experiences and preferences regarding student participation of a more diverse student population. Overall, students indicate they are willing to participate more actively in both roles as advisers and partners than they currently do.

In chapter 4, the focus shifts towards prerequisites of a SSP. Previous studies showed interest of students' perspectives, however, also revealed some conditions need to be met. To shed more light on this topic a questionnaire study was conducted measuring to what extent a supportive organisation, commitment, communication, and reciprocal respect predict students' preference for SSP. These scales were constructed based on partial existing questionnaires and partially developed by the authors' insights from literature. In this study, 129 second year Biomedical Sciences students filled in the questionnaire about SSP and its prerequisites, which has resulted in a response rate of 57\%. To examine the relationships between the prerequisites and students' preferences of SSP, a path analysis was conducted. We hypothesized that a supportive organisation should be met first, and commitment, communication, and reciprocal respect served as mediating variables between a supportive organisation and students' preferences of SSP. Results suggest that supportive organisation is an important prerequisite for commitment, communication, and reciprocal respect. Commitment was found to be a direct predictor of SSP. This chapter supports the hypothesis that a supportive organisation is an important prerequisite for enhancing commitment which predicts students' preferences for SSP.

Chapter 5 reports on a semi-structured interview study investigating staff members' perspectives about SSPS, and under which conditions SSP can contribute to enhancing educational quality according to staff members. Fourteen staff members participated in the interviews. We performed a template analysis following the six-step procedure described by Brooks et al. (2015). Bovill and Bulley (2011)'s levels of student participation were used as sensitizing concepts when analysing the data. In the results, we identified three main perspectives: Teachers teach and students study (i.e. teacher have expertise and students acquire knowledge), teachers teach and value student feedback (i.e. teachers use student feedback to improve their teaching), and teachers and students co-create (i.e. they both contribute substantially to improving education and learn from each other). In order to reach the co-create level of partnership the following criteria were discussed: Staff members are open and aware to involve students, they create 
dialogues with students, students are motivated to co-create, the organisation is supportive, and staff members have the final responsibility. The current chapter shows that staff members' perspectives on developing a partnership with students seem to shift: From more traditional approaches in which students have limited space in course redesign, to perspectives in which student input is valued, and finally a setting in which both students and staff members co-create education and learn from each other when improving education. Struggles reported deal with perceived differences in responsibilities.

Student participation, in different shapes and forms, has received growing interest in research. That implies more is known about the topic, on the other hand, a wide range of terminology and approaches are used. In chapter 6, we aimed to unravel the different terminology and approaches to student participation and to situate this terminology in existing models on student participation. The three most frequently used terms were design-based research (DBR), participatory design (PD), and co-creation. These terms were distinguished based on the following aspects: Definitions, aims, which stakeholders are involved, the outcomes and benefits, and related terms. The results show that DBR is a collaboration of researchers and educational practices in which they develop answers to educational problems and advance theoretical understanding. PD is a collaboration of all stakeholders including students in which they design and develop innovations that are tailored to the local situation, and co-creation is a close collaboration of students and teachers in which they intensify student participation and improve teaching and learning. We further applied the most frequently used terms to the model of Druin (2002) and to Bovill and Bulley (2011)'s "ladder of student participation". The similarity between DBR, PD, and co-creation is the valuing of the input of different stakeholders in the educational design process. Differences lie in the degree to which the student is the central stakeholder and the focus on instructional theory building. The degree to which the student is the central stakeholder increases from DBR to co-creation, while the focus on theory decreases. It is therefore important that the level of student participation is aligned with the purpose of the approach.

Chapter 7 provides an overarching discussion of the previous chapters in this dissertation. The main conclusions, strengths and weaknesses, suggestions for future research, and practical implications are described. A main conclusion is that students and staff members are willing to participate more actively than they currently do in enhancing educational quality together, while certain prerequisites such as good communication among the stakeholders and a supportive organisation should be met. 


\section{References}

Bovill, C., \& Bulley, C. (2011). A model of active student participation in curriculum designexploring desirability and possibility. In C. Rust (Ed.), Improving Student Learning (18) Global theories and local practices: Institutional, disciplinary and cultural variations. (pp. 176-188). Oxford: the Oxford centre for staff and educational development.

Brooks, J., McCluskey, S., Turley, E., \& King, N. (2015). The Utility of Template Analysis in Qualitative Psychology Research. Qualitative Research in Psychology, 12(2), 202-222. https://doi.org/10.1080/14780887.2014.955224

Cook-Sather, A., Bovill, C., \& Felten, P. (2014). Engaging students as partners in learning and teaching: A guide for faculty (First; A. Cook-Sather, C. Bovill, \& P. Felten, eds.). San Francisco: Jossey-Bass.

Druin, A. (2002). The role of children in the design of new technology, Behaviour \& Infirmation Technology. Behaviour \& Information Technology, 21(1), 1-25. 


\section{Samenvatting}

Het doel van dit proefschrift is om bij te dragen aan het opbouwen van student-docent partnerschappen (SDP's). SDP kan gedefinieerd worden als: ‘Een gezamenlijk, wederkerig proces waarbij alle deelnemers de mogelijkheid hebben om gelijkwaardig bij te dragen, maar niet noodzakelijkerwijs op dezelfde manier, aan curriculaire of pedagogische conceptualisering, besluitvorming, implementatie, onderzoek of analyse' (Cook-Sather, Bovill, \& Felten, 2014, p. 6-7). Het concept kan een waardevolle toevoeging zijn om leer- en onderwijspraktijken te verbeteren door de unieke ervaringen en perspectieven van studenten en docenten mee te nemen. Hoofdstuk 1 start met een algemene introductie op dit onderwerp. Er is momenteel nog veel onbekend over hoe studenten hun huidige betrokkenheid bij het verbeteren van onderwijs ervaren en wat hun voorkeuren zijn. Ondanks dat er al veel rapporten met voorbeelden over SDP's zijn geschreven, ontbreekt voornamelijk empirisch bewijs. Dit roept vragen op zoals: Zijn alle studenten bereid deel te nemen aan SDP's of is dit alleen interessant voor studenten die al actief betrokken zijn? Of is het voldoende als studenten feedback geven in een adviseursrol? Tegelijk beschrijven we dat we verwachten dat respect, wederkerigheid, verantwoordelijkheid/eigenaarschap, empowerment en betrokkenheid variabelen zijn die cruciaal zijn voor een succesvol SDP. Wij vragen ons af welke voorwaarden door studenten als meest belangrijk worden ervaren. En hoe zit het met het perspectief van docenten? Zij kunnen ook barrières ervaren om SDP's te implementeren. De perspectieven van zowel studenten als docenten op deze SDP's zijn tot nu toe nog weinig onderzocht. Het hoofddoel van dit proefschrift is het onderzoeken van de perspectieven van studenten en docenten. De onderzoeksvragen zijn:

1. Wat zijn de huidige ervaringen en voorkeuren van studenten met betrekking tot SDP's en wat zijn de voorwaarden voor het leveren van een nuttige bijdrage aan SDP's? (Hoofdstukken 2, 3 en 4)

2. Wat zijn de opvattingen van docenten over SDP's en over de voorwaarden die SDP's effectief maken? (Hoofdstuk 5)

Hoofdstuk 2 beschrijft een mixed-methods onderzoek met het doel om te onderzoeken op welke manier studenten momenteel de student-docent 
samenwerking ervaren. Om preciezer te zijn, hebben we onderzocht of studenten bereid zijn deel te nemen aan SDP's, hoe de ervaringen van studenten verschillen van hun gewenste situatie en waarom en onder welke omstandigheden studenten hun bijdrage aan SDP's als effectief ervaren. Dit onderzoek is uitgevoerd onder een specifieke groep studenten, namelijk studenten die al actief betrokken waren bij bijvoorbeeld evaluatiepanels, blokplanningsgroepen of in het managementteam. Er zijn vragenlijsten afgenomen en focusgroepen gehouden om meer inzicht te krijgen in de percepties van studenten. De resultaten geven aan dat studenten momenteel nog geen volledige SDP's ervaren. Cruciaal daarbij is dat ze ervaren dat ze een beperkte invloed hebben bij gedeelde besluitvormingsprocessen en implementatieprocessen. Studenten voelen zich nog niet altijd betrokken bij het implementatieproces. Hun invloed beperkt zich tot voornamelijk het geven van advies. De resultaten over de voorkeuren van studenten geven aan dat studenten bereid zijn om meer betrokken te zijn bij onderwijsverbetering en dat ze het liefst gezien worden als gelijkwaardige partners, hoewel hun input niet hetzelfde hoeft te zijn als de input van docenten gezien de verschillen in deskundigheid. Op de vraag wat er nodig is om tot die situatie te komen, noemen studenten het belang van het verduidelijken van de rolverdeling, wie welke rollen kan vervullen en wat hun verantwoordelijkheden zijn. Rollen dienen geformaliseerd te worden, anderzijds mag het informele karakter niet verloren gaan. Deze studie geeft een dieper inzicht in hoe een SDP wordt ervaren door studenten die al actief betrokken zijn, waar zij de voorkeur aan geven en onder welke omstandigheden een partnerschap effectief zou kunnen zijn. Duidelijk is dat aan een aantal specifieke voorwaarden moet worden voldaan om effectieve partnerschappen mogelijk te maken.

Hoofdstuk 3 beschrijft een kwantitatieve studie waarin de focus ligt op het verkennen van het perspectief van de bredere studentenpopulatie met betrekking tot ervaringen en voorkeuren voor de rol als adviseur om docenten in staat te stellen het onderwijs te verbeteren, en voor de rol als partner in een SDP. Dat wil zeggen, is het vooral wenselijk in de perceptie van een groep selecte studenten die al nauw betrokken is bij onderwijsadvies commissies, of ook voor studenten die hier niet in actief zijn? Is deze laatste groep ook geïnteresseerd in een SDP? Het onderzoek is bedoeld om erachter te komen hoe de (potentiële) kloof tussen de huidige ervaringen van studenten en hun voorkeuren overbrugd kan worden. Er is een vragenlijst afgenomen waarin beide rollen voor de huidige en de gewenste situatie werden gemeten en waarbij er twee open vragen werden gesteld. De 
resultaten laten zien dat beide groepen studenten een voorkeur hebben voor een actievere rol dan momenteel het geval is. Enerzijds willen ze zich sterker profileren als adviseur door actief feedback te geven om de onderwijskwaliteit te verbeteren. Anderzijds zijn studenten bereid om de studentparticipatie een stap verder te brengen en partner te worden door bijvoorbeeld mee te helpen bij het (her)ontwerpen van cursussen. De suggesties van studenten over hoe een SDP bereikt kan worden, zijn als volgt: Ze willen transparantie over wat er met hun verbetersuggesties gebeurt, ze willen de dialoog tussen studenten en docenten die bij onderwijsontwikkeling betrokken zijn verbeteren en ze willen graag open informele bijeenkomsten om het perspectief van de brede studentpopulatie bij onderwijsverbetering te kunnen betrekken. De ervaringen en voorkeuren met betrekking tot studentparticipatie van een meer diverse studentpopulatie zijn in dit hoofdstuk in kaart gebracht. Over het algemeen geven studenten aan dat ze bereid zijn om actiever betrokken te zijn in beide rollen: als adviseur en als partner, dan momenteel het geval is.

In hoofdstuk 4 verschuift de focus naar de voorwaarden voor een SDP. Eerdere studies lieten het perspectief van studenten zien, maar toonden ook aan dat er aan een aantal voorwaarden moet worden voldaan. Om meer licht te werpen op dit onderwerp is een vragenlijstonderzoek uitgevoerd om te meten in hoeverre een ondersteunende organisatie, betrokkenheid, communicatie en wederzijds respect voorspellend zijn voor studenten hun gewenste SDP-situatie. Deze schalen zijn gedeeltelijk ontwikkeld op basis van bestaande vragenlijsten en gedeeltelijk op basis van de inzichten van de auteurs uit de literatuur. 129 Tweedejaarsstudenten Biomedische Wetenschappen vulden de vragenlijst over SDP's en de voorwaarden in, wat resulteerde in een respons van 57\%. De relaties tussen de voorwaarden en de door de studenten gewenste situatie van SDP is onderzocht door middel van een pad-analyse. De resultaten suggereren dat een ondersteunende organisatie een belangrijke voorwaarde is voor betrokkenheid, communicatie en wederzijds respect. Betrokkenheid bleek een directe voorspeller van SDP's te zijn. Dit hoofdstuk ondersteunt de hypothese dat een ondersteunende organisatie een belangrijke voorwaarde is voor het vergroten van betrokkenheid dat op zijn beurt voorspellend is voor de gewenste SDP-situatie van studenten.

Hoofdstuk 5 doet verslag van een semi-gestructureerd interviewonderzoek waarin is onderzocht wat de perspectieven van docenten op SDP's zijn en onder welke voorwaarden SDP's kunnen bijdragen aan het verbeteren van 
de onderwijskwaliteit volgens docenten. Veertien docenten namen deel aan de interviews. We hebben een template-analyse uitgevoerd volgens de zes stappen procedure zoals beschreven door Brooks et al. (2015). De niveaus van studentparticipatie van Bovill en Bulley (2011) werden gebruikt als sensitizing concepten bij de data-analyse. We hebben drie hoofdperspectieven in de resultaten geïdentificeerd: Docenten doceren en studenten studeren (d.w.z. docenten hebben expertise en studenten verwerven kennis), docenten doceren en waarderen feedback van studenten (d.w.z. docenten gebruiken feedback van studenten om hun onderwijs te verbeteren), en docenten en studenten co-creëren (d.w.z. ze dragen allebei substantieel bij aan het verbeteren van onderwijs en leren van elkaar). Docenten noemden de volgende voorwaarden: Docenten staan open voor en zijn zich bewust van de mogelijkheid om studenten te betrekken, ze gaan de dialoog aan met studenten, studenten zijn gemotiveerd om te co-creëren, de organisatie is ondersteunend en docenten hebben de eindverantwoordelijkheid. Dit hoofdstuk laat zien dat de perspectieven van docenten lijken te verschuiven: Van meer traditionele benaderingen waarin studenten beperkte ruimte hebben om mee te werken aan het herontwerpen van cursussen, naar perspectieven waarin de input van studenten wordt gewaardeerd, en tenslotte naar een omgeving waarin studenten en docenten onderwijs co-creëren en van elkaar leren bij het verbeteren van onderwijs. De uitdagingen zitten hem in de verschillende perspectieven op verantwoordelijkheden.

In wetenschappelijk onderzoek is er een toenemende belangstelling voor studentparticipatie in verschillende vormen en maten. Dat betekent dat er meer bekend wordt over het onderwerp, maar tegelijkertijd wordt er een breed scala aan terminologie en benaderingen gebruikt. In hoofdstuk 6 ontrafelen we de terminologie en verschillende benaderingen van studentparticipatie en plaatsen we deze terminologie in bestaande modellen over studentparticipatie. De drie meest gebruikte termen zijn design-based research (DBR), participatory design (PD) en co-creatie. Deze termen worden onderscheiden op basis van de volgende aspecten: Definities, doelen, welke stakeholders betrokken zijn, de uitkomsten en de voordelen en gerelateerde termen. De resultaten laten zien dat DBR een samenwerking is van onderzoekers en de onderwijspraktijk waarin ze antwoorden vinden op onderwijsproblemen en tegelijkertijd het theoretische inzicht versterken. PD is een samenwerking van alle stakeholders inclusief studenten waarin ze innovaties ontwerpen en ontwikkelen die zijn afgestemd op de lokale situatie. 
Co-creatie is een nauwe samenwerking van studenten en docenten waarin ze de studentparticipatie intensiveren en het doceren en leren verbeteren. We hebben verder de meest gebruikte termen toegepast op het model van Druin (2002) en op de "ladder van studentparticipatie" van Bovill en Bulley (2011). De overeenkomst tussen DBR, PD en co-creatie is de waardering van de input van verschillende stakeholders in het onderwijsontwerpproces. De verschillen zitten in de mate waarin de student de centrale stakeholder is en de focus op theorievorming. De mate waarin de student de centrale stakeholder is neemt toe van DBR naar co-creatie, terwijl de focus op theorie afneemt. Het is daarom belangrijk dat het niveau van studentparticipatie aansluit bij het doel van de aanpak.

Hoofdstuk 7 geeft een overkoepelende discussie van de voorgaande hoofdstukken in dit proefschrift weer. De belangrijkste conclusies, de sterke en zwakke punten, suggesties voor vervolgonderzoek en praktische implicaties worden hier beschreven. Een hoofdconclusie is dat studenten en docenten bereid zijn om actiever betrokken te zijn in gezamenlijke onderwijsverbetering dan nu het geval is, waarbij er aan bepaalde voorwaarden zoals goede communicatie tussen de stakeholders en een ondersteunende organisatie moet worden voldaan. 


\section{Referenties}

Bovill, C., \& Bulley, C. (2011). A model of active student participation in curriculum designexploring desirability and possibility. In C. Rust (Ed.), Improving Student Learning (18) Global theories and local practices: Institutional, disciplinary and cultural variations. (pp. 176-188). Oxford: the Oxford centre for staff and educational development.

Brooks, J., McCluskey, S., Turley, E., \& King, N. (2015). The Utility of Template Analysis in Qualitative Psychology Research. Qualitative Research in Psychology, 12(2), 202-222. https://doi.org/10.1080/14780887.2014.955224

Cook-Sather, A., Bovill, C., \& Felten, P. (2014). Engaging students as partners in learning and teaching: A guide for faculty (First; A. Cook-Sather, C. Bovill, \& P. Felten, eds.). San Francisco: Jossey-Bass.

Druin, A. (2002). The role of children in the design of new technology, Behaviour \& Infirmation Technology. Behaviour \& Information Technology, 21(1), 1-25. 


\section{Impact chapter}

\section{What was the main objective of the research described in this dissertation and what are its most important results and conclusions?}

The aim of this PhD dissertation was to explore student-staff partnerships (SSPs). An SSP can be defined as a collaboration between students and staff members in which students not only provide feedback to improve education, but also contribute to its evaluation, design or redesign and to its implementation. During this process, both students and staff members contribute from their perspective, experience and knowledge (Cook-Sather, Bovill, \& Felten, 2014). In this dissertation we examined students' current experiences and preferences regarding SSPS, staff members' conceptions of SSPs and the prerequisites as perceived by both students and staff members. Five studies were conducted using qualitative, quantitative, mixed-methods and literature study designs. From these studies we learnt that students would like to be more actively involved as partners in the process of improving education. Concurrently, we also concluded that students did not yet fully experience the level of student participation they preferred. This held true for both students who were already actively involved in improving education and those who were not. Staff members, however, stuck to the idea that students' role is to provide feedback and were oblivious of alternative ways to collaborate. What is clear, however, is that staff members were open to SSP formation as long as they would still have the final say in decisions about improving education. Overall, we can conclude that students and staff members were on the same page. Although both students and staff members did not yet experience fully fledged SSPs, they were willing to move in that direction. To render SSPs successful, certain conditions such as good communication and a supportive organisation should be met.

\section{In what ways do the results from this research contribute to science, social sectors and to social challenges?}

Traditionally, students have been involved in evaluating education by filling in endof-course evaluation questionnaires and by serving on advisory bodies. Whilst the feedback received from students in these ways does offer staff members rich insights into teaching and the effectiveness of courses and whilst they do have the opportunity to act on it, with limited opportunities for reflection and 
dialogue it does not always lead to changes in practice (Blair \& Noel, 2014; Golding \& Adam, 2016). By combining students and staff members' experiences and knowledge, SSPs offer a new perspective that can lead to enhanced educational practices (Abbot \& Cook-Sather, 2020; Matthews, Dwyer, Hine, \& Turner, 2018). We have learnt that students and staff members are willing to strengthen student participation and move towards SSPs to enhance the quality of education. Yet, stepping away from the traditional learning versus teaching roles for students and staff members, respectively, and moving towards a context in which both partners co-create teaching whilst learning from each other is easier said than done. The present dissertation has provided suggestions based on students and staff members' experiences and preferences on how to put SSPs into practice, such as having a dialogue to learn from, with and about each other by exploring each other's unique perspective.

\section{To whom can the results be of interest/relevance and why?}

The results and conclusions of the present dissertation can be of interest to multiple stakeholders. Not only can they obviously serve students and staff members, such as course coordinators, trainers, lecturers, tutors and mentors, but they can also be meaningful to management teams and policymakers. This dissertation can help these stakeholders to reflect on how they experience student participation and what their preferences are regarding the involvement of students as partners in education. Our research offers several suggestions on how to render SSPs successful that can be relevant to them, including: (1) Ensure that your organisation is supportive and has a clear vision for student participation; (2) Strengthen students and staff members' commitment to improve education together; (3) Create dialogues between students and staff members; and (4) Help both students and staff members to respect each other and take each other seriously. These suggestions can help both students and staff members who wish to participate in SSPs. In chapters 3 and 5, we have demonstrated that a supportive organisation is key, and that this is a prerequisite that should be met first before SSPs can be achieved. In this sense, a 'supportive organisation' refers to a culture in which collaboration and teamwork are valued and rewarded and students are seen as valuable partners not only when it comes to evaluating education and providing advice, but also in designing or redesigning, implementing and continuously improving education (Bovill 2019; Chapman, Blatchford, and Hughes 2013). 


\section{In what way can these target groups be involved and informed about the research results, so that the knowledge gained can be used in the future?}

To reach a diverse audience, we submitted the contents of chapters 2-6 of the present dissertation to general higher education journals as well as to medical education journals. Three of these chapters (chapters 2, 5 and 6) have been published by now and chapters 3 and 4 are currently submitted to peer-reviewed journals. Moreover, we presented chapters 2, 3, 5 and 6 at national and international conferences on general education (ORD and EARLI) and medical education (NVMO and $\mathrm{AMEE}$ ). I have also been invited by the Staff Development Task Force at Maastricht University (UM) and the Department of Methodology and Statistics at Utrecht University (UU) to present our research. Within our own institution, we frequently shared our results with stakeholders during various meetings. I have also presented the studies to student associations and have written summaries of the results to both students and staff members who were involved in the studies. Furthermore, I have shared our Students-As-Partners Questionnaire with diverse institutions worldwide. Finally, I have shared our research findings on social media platforms such as Twitter, using the hashtag studentsaspartners, and the student voice research and practice group on Facebook. Whilst the present dissertation has focused on experiences and preferences regarding SSPS, we did not yet put SSPs into practice. Nevertheless, the results of this dissertation can inform SSP implementation in practice and its subsequent evaluation. 


\section{References}

Abbot, S., \& Cook-Sather, A. (2020). The productive potential of pedagogical disagreements in classroom-focused student-staff partnerships. Higher Education Research and Development, 39(7), 1396-1409. https://doi.org/10.1080/07294360.2020.1735315

Blair, E., \& Noel, K. V. (2014). Improving higher education practice through student evaluation systems: Is the student voice being heard? Assessment \& Evaluation in Higher Education, 39(7), 879-894. https://doi.org/10.1080/02602938.2013.875984

Bovill, C. (2019). Student-staff partnerships in learning and teaching: An overview of current practice and discourse. Journal of Geography in Higher Education, 43(4), 385-398. https://doi.org/10.1080/03098265.2019.1660628

Chapman, P., Blatchford, S., \& Hughes, E. (2013). Lightening up the dark side: A partnership approach between a students' union and the university. In C. Nygaard, S. Brand, P. Bartholomew, \& L. Millard (Eds.), Student engagement: Identity, motivation and community (pp. 271-290). Oxfordshire: Libri Publishing.

Cook-Sather, A., Bovill, C., \& Felten, P. (2014). Engaging students as partners in learning and teaching: A guide for faculty (First; A. Cook-Sather, C. Bovill, \& P. Felten, eds.). San Francisco: Jossey-Bass.

Golding, C., \& Adam, L. (2016). Evaluate to improve: Useful approaches to student evaluation. Assessment and Evaluation in Higher Education, 41(1), 1-14. https://doi.org/10.1080/02 602938.2014.976810

Matthews, K. E., Dwyer, A., Hine, L., \& Turner, J. (2018). Conceptions of students as partners. Higher Education, 76(6), 957-971. https://doi.org/10.1007/s10734-018-0257-y 


\section{Dankwoord}

Promoveren doe je niet alleen. Zoals ik ervan overtuigd ben dat het combineren van student en docent perspectieven tot onderwijsverbetering kan leiden, ben ik ervan overtuigd dat het combineren van perspectieven ook mijn proefschrift verbeterd heeft. Daarom wil ik met dit dankwoord graag de perspectieven van verschillende personen bedanken.

Diana, mijn promotor. Ik wil je bedanken voor je sterke, kritische en snelle feedback. Ik heb veel geleerd van onze afspraken waarin we onze gedachten uittekenden op een whiteboard. Je hebt me geleerd om de boodschappen zo eenvoudig mogelijk te verwoorden en echt bij de kern te blijven. We konden altijd een extra afspraak inplannen wanneer dat nodig was en je was bijna altijd aanwezig bij mijn presentaties op congressen. Daarnaast vond ik het ook heel bijzonder en leuk dat je mij en medepromovendi uitnodigde om bij je te komen eten. Ik had mij geen betere en fijnere promotor kunnen voorstellen.

Ineke, mijn co-promotor en dagelijks begeleider. Ik waardeer hoe je aan mij als persoon dacht. Je hebt oog voor de combinatie van hoe het met mijn werk ging en ook hoe het met mij persoonlijk ging. Jij hielp mij bij het vinden van de balans in een tandje bij zetten versus dagen vrij nemen wanneer het nodig was. Ik waardeer jouw snelle, kritische en sterke feedback. Wat vond ik het fijn om met jou samen te mogen werken. leder PhD team zou een Ineke kunnen gebruiken.

jill, mijn co-promotor. Jij stond altijd voor mij klaar om te brainstormen. Door met jou te sparren begreep ik mijn gedachten ook beter. Je hielp me met het vertalen van die gedachten zodat anderen het ook konden begrijpen. Jouw feedback zorgde iedere keer weer voor nieuwe inzichten. Jouw inzichten en verhelderende gedachten waren onmisbaar in mijn promotietraject. Ik heb mijn hele team als een heel sterk en warm team ervaren.

Annemarie, jij was tijdens mijn eerste jaar een belangrijk deel van mijn $\mathrm{PhD}$ team. Een goede begeleider is een goed begin, en een goed begin is het halve werk.

Deelnemers aan mijn onderzoeken, studenten en docenten. Jullie zijn de kern van mijn proefschrift. Dit proefschrift is er door jullie en voor jullie. Bedankt.

The co-creation special interest group. I would like to thank you for the international perspective, the insights from physician-patient relationships and other contexts. I valued our meetings in which we shared our successes and challenges. Special thanks to Karen for setting up this special interest group. 
De bewoners van kamer M4.15, mijn favoriete plek in UNS60. Toen ik begon kwam ik bij Jolien op de kamer en vlak na mij kwam Serge er ook bij. Door jullie heb ik langzaamaan het Maastrichtse dialect leren verstaan. Daarnaast wil ik Derk, Koos, Felicitas, Juliët, Anne en Michelle bedanken. Ik heb met veel plezier in alle wisselende samenstellingen van de kamer gezeten en heb veel geleerd van de leuke gesprekken over zulke verschillende promotietrajecten. Juliët, Felicitas, Anne, Michelle en Lianne, ook bedankt voor de 'Is het Teksel' of Tessel?' appgroep en de gezellige momenten samen.

Juliët en Felicitas, twee van mijn kamergenoten die dierbare vriendinnen zijn geworden. Ik wil jullie apart benoemen. Juliët, ongeveer een halfjaar na de start van mijn PhD kwam jij bij onze afdeling. Wat klikte het al ontzettend goed vanaf het begin en wat was het fijn om nog iemand uit het noorden te ontmoeten. Ik waardeer onze serieuze gesprekken, jouw droogheid en jouw zorgzaamheid enorm. Felicitas, na iets meer dan een jaar kwam jij ook bij ons op de afdeling, net op het moment dat we besloten de indeling van de kamers overhoop te gooien. Zo kwam er naar verluid een 'serieuze Duitse vrouw' bij ons op de kamer. Dat bleek (gelukkig) niet helemaal te kloppen. Je bleek een zachtaardig en zorgzaam persoon. Het is een eer dat jij mijn paranimf wilt zijn, dankjewel. Juliët en Fe, wat zijn onze dagjes en weekendjes weg ontzettend leuk en wat kijk ik ernaar uit om met jullie te proosten op alle mooie momenten die nog in het verschiet liggen. Ik ben trots op jullie en kijk ook uit naar jullie verdedigingen. Ik kijk er altijd weer naar uit om weer naar jullie in Maastricht te komen. Maastricht is echt in mijn hart gaan zitten.

All other (former) fellow PhD students: Sanne S, Sanne R, Joy, Luotong, Fatemeh, Dominique, HQ, Cindy, Guy, Lorette, Andrea, Carolin, Erdem, Eveline and Suzanne. I would like to thank you for your help content-wise during the PhD platforms and at the conferences, and for all the social activities like the lunches, the PhD days and the Friday evenings before Vastelaovend.

Het secretariaat: Nicky (ook voor een fijne koffie klatsj), Lilian, Ryan, Audrey en Hennie. Jullie hulp en ondersteuning is onmisbaar in een promotietraject.

Alle andere collega's van O\&O. In het speciaal dank aan Arno, Jeroen en Carlos met wie ik over statistiek kon praten, en Janneke met wie ik over kwalitatief onderzoek kon praten. Daarnaast wil ik Angelique bedanken voor de taalbewerking van de meeste hoofdstukken. Ook dank aan de taakgroep Programma Evaluatie (PE). 
Het CBR, in het specifiek het PM Theorie team. Ik wil jullie bedanken voor de mooie nieuwe uitdaging. Ik geniet ervan om mij meer te kunnen ontwikkelen op het gebied van toetsing en verkeer.

Oud-studiegenoten en docenten van mijn bachelor Onderwijskunde en research master Educational sciences: Learning in Interaction. Bedankt voor de onderwijskundige basis van waaruit ik mij verder heb kunnen ontwikkelen in Maastricht.

Mijn onderwijskunde vrienden uit mijn studententijd: Denise, Angela, Laurien, Kaylee en Bas. Ik wil jullie bedanken voor het voortzetten van onze vriendschappen en de nog altijd interessante onderwijskundige discussies. Wat heerlijk om avonden, dagjes en weekendjes met jullie weg te gaan en het naast over onderwijskunde, ook over van alles en nog wat te kunnen hebben.

Mijn vrienden van buiten de onderwijskunde: Anneloes, Lisette, Yasmine, Qiqi, Marie-Chantal, Wendy, Heleen, Lisanne, Sari, Gitta, Jeanne, Lotte en Koos. Ik wil jullie bedanken voor de ontspanning en de afleiding. Jullie hebben mij de ruimte gegeven om voor mijn PhD naar Maastricht te vertrekken en jullie stonden voor mij klaar als ik dat nodig had. We konden elkaar niet zo veel zien als ik had gewild, maar ik ben dankbaar dat jullie achter mij stonden. Jullie zorgden ervoor dat ik niet alleen maar met mijn proefschrift bezig was. Anneloes, wat vond ik het fantastisch dat jij ook één van mijn jaren in Maastricht hebt gewoond. Zo konden we samen integreren in het zuiden.

Mijn schoonfamilie, Marleen en Frank, en Cathelijne en Thieu. Marleen en Frank, wat vind ik het fijn hoe warm jullie mij in de familie verwelkomd hebben. Wat was het ook een mooie combinatie: logeren bij mijn schoonouders in een voormalige school en naar een onderwijscongres (ORD) gaan. Cathelijne en Thieu, ik wil jullie ook bedanken voor de ontspanning en dat we het ook over onderwijs kunnen hebben. Het is mooi om mijn passie voor onderwijs met jullie te kunnen delen.

Mijn zus Louise en zwager Erik. Lo, wat ben ik trots op jou en je lieve man. Het is bijzonder dat we elkaar begrijpen in wat we mee hebben gemaakt tijdens een PhD. Juist de combinatie van dat jij mijn zus bent en ook een PhD doet, maakte het voor mij gelijk duidelijk dat ik jou als paranimf wilde vragen. Bedankt dat je deze uitnodiging aan wilde nemen en nu letterlijk en figuurlijk achter mij staat.

Mijn tweelingzus Rosanne. Ik wil jou ook laten weten dat ik trots op je ben. We zullen er altijd voor elkaar zijn. Ik wil je daarnaast ook bedanken voor het 
prachtige ontwerp van dit proefschrift. Er was maar één iemand die ik hiervoor wilde vragen en dat was jij. Bedankt voor het visualiseren van mijn gedachten, maar ook zeker voor de ontspanning samen. Ik ben heel benieuwd naar wat jouw creativiteit jou verder gaat brengen.

Oma, Jannie. Ik wil je bedanken voor de fijne momenten wanneer ik op bezoek kwam. Ik vind het bijzonder hoeveel ik met je kan bespreken. Het overlijden van pake en de coronacrisis maakten het afgelopen jaar ook niet makkelijk. Wat ben ik blij en opgelucht dat je de tweede vaccinatie binnen hebt. Wanneer het weer veilig kan, geef ik je een knuffel.

Pap en mam, Gerard en Jellie. Ik wil jullie bedanken voor het stimuleren om alles uit mij te halen wat er in zit. Jullie hebben mij altijd gesteund. Wat was het fijn wanneer ik jullie weer kon zien. Dat pap dan al met zijn armen wijd open stond om mij op te vangen (als er geen pandemie was). Dat mam altijd iets lekkers in huis haalde. Jullie hebben mij geleerd om voor mijzelf op te komen, te volharden wanneer ik denk dat het nodig is, om door te zetten, om zo veel mogelijk uit mijzelf te halen. Dat terwijl ik goed voor mijzelf blijf zorgen en er ook voor anderen blijf zijn met een opendeurbeleid waar iedereen altijd welkom is. Jullie hebben mij een basis gegeven waar ik verder mee kan.

Remy, ooit mijn vriend, nu mijn verloofde en op het moment van promoveren zelfs mijn man. Ik wil jou ontzettend bedanken voor hoe jij altijd voor mij hebt klaar gestaan. Vanaf het moment dat ik de vacature online zag staan, steunde je mijn keuzes volledig, ook al betekende dat voor enkele jaren een langeafstandsrelatie. Het leuke was dat we er op deze manier allebei een vakantiehuisje bij kregen: jij in Maastricht en ik in Veenendaal. Toch ben ik heel blij dat we na tweeënhalf jaar heen en weer reizen relatief spontaan hebben gekozen om samen te gaan wonen in Den Bosch. Wat vind ik ons ontzettend leuk samen en wat vul jij mij fantastisch aan. Jij bent mijn rust. Ook geniet ik enorm van jouw humor. Ik vind je een vreemd figuur in positieve zin. Waar ik soms struikelde met mijn proefschrift, struikelde jij soms met je masterscriptie, maar samen kwamen we weer overeind. Ik ben trots op je en heel gelukkig met je. Dankjewel!

Julius, onze kater, wat ben jij een fantastische toevoeging aan ons huishouden. Wat is het elke dag toch weer heerlijk comfortabel met jou erbij. Je accepteerde het (na wat gemiauw) dat ik je de laatste maanden in de weekenden minder aandacht kon geven dan je zou willen, zodat ik mijn proefschrift kon afronden. Dank voor je begrip. Ik ben trots op je. 


\section{About the author}

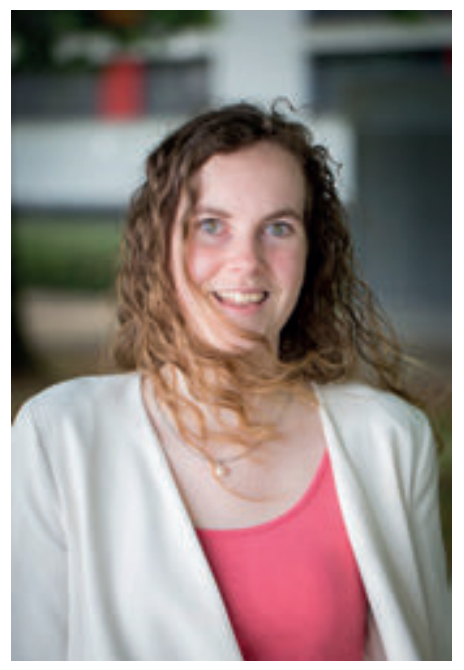

Samantha Eeke Martens was born in Nieuwegein on September 9, 1992. During her primary education and pre-university education in Schoonhoven she became fascinated by learning and teaching. Samantha decided to study Educational Sciences at Utrecht University including an Erasmus semester at the University of Oslo. She received her Bachelor's degree in Educational Sciences from Utrecht University in 2014. She obtained her research master's degree in Education Sciences: Learning in Interaction in 2016. She worked as a research assistant at Utrecht University during her master program. Samantha started her PhD project at the School of Health Professions Education of Maastricht University in 2016. Currently, she works as product manager within the division theory at the Central Office for Motor Vehicle Driver Testing (Centraal Bureau Rijvaardigheidsbewijzen, CBR). 


\section{SHE dissertation series}

The SHE dissertation Series publishes dissertations of PhD candidates from the School of Health Professions Education (SHE) who defended their PhD theses at Maastricht University. The most recent ones are listed below. For more information go to: https://she.mumc.maastrichtuniversity.nl

Schillings, M. (06-07-2021) Talking about feedback: Face-to-face peer dialogue about written feedback

Wilbur, K. (05-07-2021) NO WHERE | NOW HERE: Context and Competency Expectations in Workplace-Based Training

Bendermacher, G. (02-07-2021) Navigating from Quality Management to Quality Culture

Ahmed Khan, R. (29-06-2021) Assessing curriculum viability in Undergraduate Medical Education

Chim, H.Q. (30-03-2021) Physical Activity Behavior and Learning in Higher Education

Dominguez, L.C. (23-02-2021) Persistence in surgical training: The role of job crafting and leadership

Bindels, E. (23-02-2021) DOING WELL, GETTING BETTER; Facilitating physicians' reflection on their professional performance

Iqbal, Z. (15-12-2020) All stakeholders matter in faculty development: Designing entrustable professional activities for small group facilitation

Tran, QT. (09-12-2020) Nationwide implementation of medical skills training laboratories in a developing country: studies from Vietnam

Pacifico, J. (30-11-2020) Making the implicit explicit: Uncovering the role of the conceptions of teaching and learning and the perceptions of the learning climate in postgraduate medical training

Nishigori, H. (17-11-2020) Why do doctors work for patients? Medical professionalism in the era of neoliberalism

Oudkerk Pool, A. (06-11-2020) Competency-based portfolio assessment Unraveling stakeholder perspectives and assessment practices

Geel van, K. (05-11-2020) Lifelong learning in radiology: all eyes on visual expertise Stammen, L. (16-10-2020) Pursuing - High-Value, Cost-Conscious Care - The Role of Medical Education 
Meulen van der, M. (15-10-2020) Assessment of physicians' professional performance using questionnaire-based tools

Matsuyama, Y. (05-10-2020) Contextual attributes fostering self-regulated learning in a teacher-centered culture: learner's professional identity formation is a trigger

Rovers, S. (16-09-2020) Growing knowledge, supporting students' self-regulation in problem-based learning

Bourgeois-Law, G. (03-09-2020) Conceptualizations of remediation for practicing physicians

Giuliani, M. (19-05-2020) A Critical Review of Global Curriculum Development, Content and Implementation in Oncology

Schreurs, S. (20-03-2020) Selection for medical school; the quest for validity

Schumacher, D. (19-03-2020) Resident Sensitive Quality Measures: Defining the Future of Patient-Focused Assessment

Sehlbach, C. (21-02-2020) To be continued.... Supporting physicians' lifelong learning

Kikukawa, M. (17-12-2019) The situated nature of validity: Exploring the cultural dependency of evaluating clinical teachers in Japan

Kelly, M. (10-12-2019) Body of knowledge. An interpretive inquiry into touch in medical education

Klein, D. (06-11-2019) The performance of medical record review as an instrument for measuring and improving patient safety

Bollen, J. (01-11-2019) Organ donation after euthanasia: medical, legal and ethical considerations

Wagner-Menghin, M. (25-09-2019) Self-regulated learning of history-taking: looking for predictive cues

Wilby, K. (02-07-2019) When numbers become words: Assessors' processing of performance data within OSCES

Szulewski, A. (20-06-2019) Through the eyes of the physician: Expertise development in resuscitation medicine

McGill, D. (29-05-2019) Supervisor competence as an assessor of medical trainees; Evaluating the validity and quality of supervisor assessments 


\section{ICO Dissertation Series}

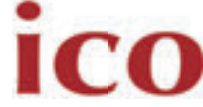

In the ICO Dissertation Series dissertations are published of graduate students from faculties and institutes on educational research within the ICO Partner Universities: Eindhoven University of Technology, Leiden University, Maastricht University, Open University of the Netherlands, Radboud University Nijmegen, University of Amsterdam, University of Antwerp, University of Ghent, University of Groningen, University of Twente, Utrecht University, Vrije Universiteit Amsterdam, and Wageningen University, and formerly Tilburg University (until 2002). The University of Groningen, and the Erasmus University Rotterdam have been 'ICO 'Network partner' in 2010 and 2011. From 2012 onwards, these ICO Network partners are full ICO partners, and from that period their dissertations will be added to this dissertation series.

List update February 8, 2021 (the list will be updated every year in January)

Figueroa Esquivel, F. (13-02-2020) Early childhood multidimensional development. A rapid and non-linear roller coaster. Groningen: University of Groningen

De Leeuw, R.R. (27-02-2020) Through the eyes of the beholder. Unfolding social participation "from within' the classroom. Groningen: University of Groningen

Schreurs, S. (20-03-20) Selection for medical school. The quest for validity. Maastricht: Maastricht University

Nugteren, M.L. (12-06-2020) What do I know and where do I go? The effects of guidance on task selection. Utrecht: Utrecht University

Wijns, N. (01-07-2020) On the hunt for regularities: An investigation of children's early patterning competencies. Leuven: KU Leuven

Duijzer, A.C.G. (25-08-2020) Reasoning about graphs in primary mathematics education. Utrecht: Utrecht University

Dijkema, S. (25-08-2020) Ready for takeoff? The relation between the type of teacher training program and daily teaching practices of Dutch beginning primary school teachers. Groningen: University of Groningen

Slot, E.M. (11-09-2020) Characterizing adolescents' interest: understanding multiplicity and dynamics in persons, objects and contexts. Utrecht: Utrecht University 
Ping, C. (24-09-2020) Understanding Teacher Educators' Professional Learning . Eindhoven: Eindhoven University of Technology

Van Rijswijk, M.M. (16-10-2020) Experiences of continuity and discontinuity in student teachers' development. Utrecht: Utrecht University

Rovers, S.F.E. (16-09-2020) Growing knowledge; Supporting students'self-regulation in problem-based learning Maastricht: Maastricht University

Langeloo, A. (17-09-2020) Multilingual and monolingual children in kindergarten classrooms: Exploring teacher-child interactions and engagement as learning opportunities. Groningen: University of Groningen

Sekeris, E. (06-10-2020) Unravelling computational estimation development in 5- to 7-year-olds Leuven: KU Leuven

Ter Beek, M. (29-10-2020) Supporting reading comprehension in history education: The use and usefulness of a digital learning environment Groningen: University of Groningen

Peppen, L.M. (25-09-2020) Fostering Critical Thinking. Generative processing strategies to learn to avoid bias in reasoning Rotterdam: Erasmus University Rotterdam

Van Geel, K., (05-11-2020) Lifelong learning in radiology: All eyes on visual expertise Maastricht: Maastricht University

Donker, M.H. (20-11-2020) In DEPTh: Dynamics of Emotional Processes in Teachers An exploration of teachers' interpersonal behavior and physiological responses Utrecht: Utrecht University

Janssen, E.M. (13-11-2020) Teaching Critical Thinking in Higher Education: Avoiding, Detecting, and Explaining Bias in Reasoning Utrecht: Utrecht University

Van den Broek, E.W.R. (09-10-2020) Language awareness in foreign language education. Exploring teachers' beliefs, practices and change processes Nijmegen: Radboud University Nijmegen

Kasch, J.A. (09-10-2020) Scaling the unscalable? Interaction and support in open online education Heerlen: Open University of the Netherlands

Otten, M. (30-10-2020) Algebraic reasoning in primary school: A balancing act Utrecht: Utrecht University

De Vrind, E. (25-11-2020) The SpeakTeach method, Towards self-regulated learning of speaking skills in foreign languages in secondary schools: an adaptive and practical approach Leiden: Leiden University 
Tacoma, S.G. (15-11-2020) Automated intelligent feedback in university statistics education Utrecht: Utrecht University

Boonk, L.M. (04-12-2020) Exploring, measuring, and evaluating parental involvement in vocational education and training Heerlen: Open University of the Netherlands

Kickert, R. (04-12-2020) Raising the bar: Higher education students' sensitivity to the assessment policy Rotterdam: Erasmus University Rotterdam

Van der Wal, N.J. (09-12-2020) Developing Techno-mathematical Literacies in higher technical professional education Utrecht: Utrecht University 



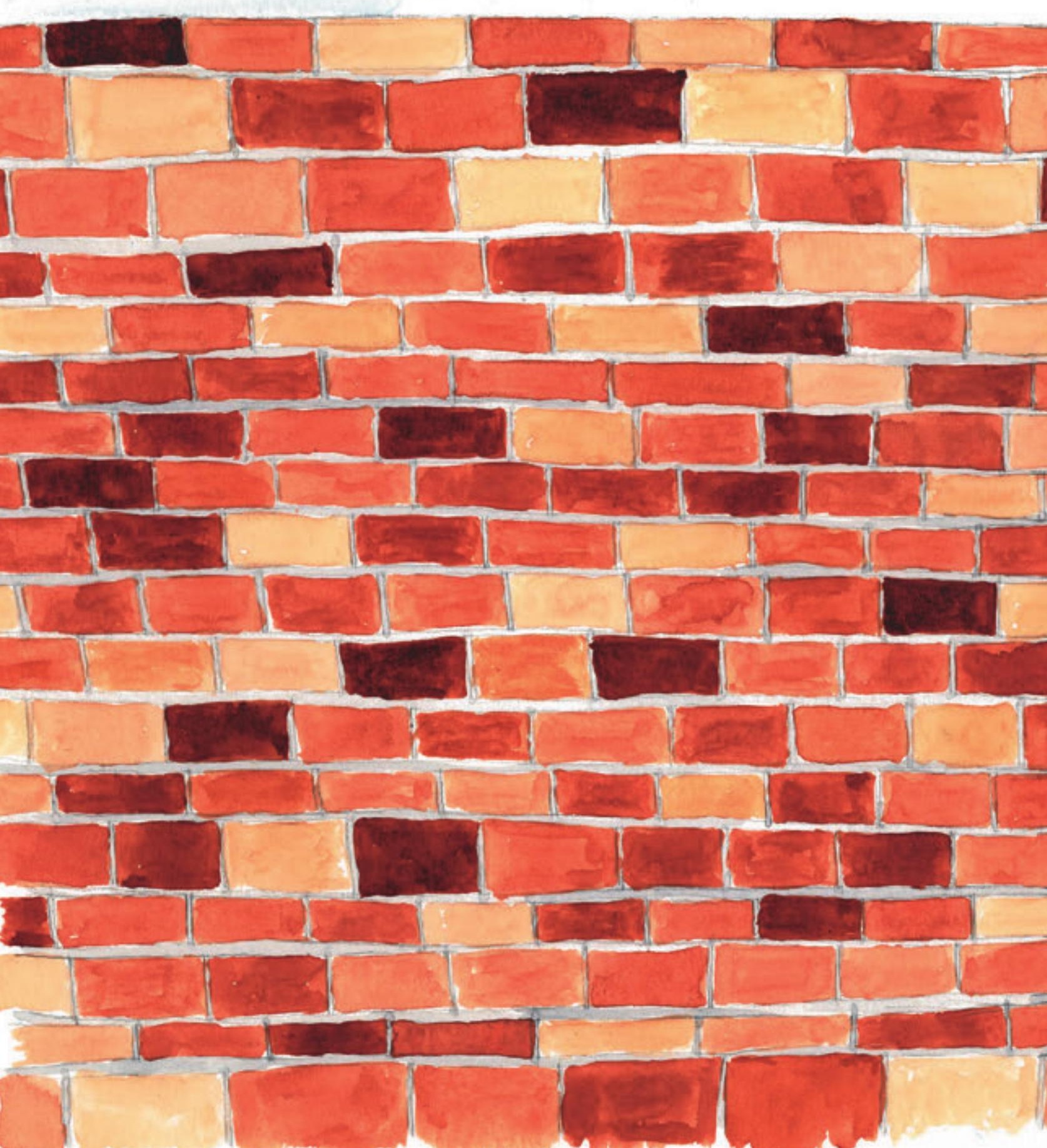

